\title{
The influence of natural and anthropogenic secondary sources on the glyoxal global distribution
}

\author{
S. Myriokefalitakis ${ }^{1}$, M. Vrekoussis ${ }^{2}$, K. Tsigaridis ${ }^{3,}{ }^{*}$, F. Wittrock ${ }^{2}$, A. Richter $^{2}$, C. Brühl $^{4}$, R. Volkamer ${ }^{5}$, \\ J. P. Burrows ${ }^{2}$, and M. Kanakidou ${ }^{1}$ \\ ${ }^{1}$ Environmental Chemical Processes Laboratory, Department of Chemistry, University of Crete, Voutes Campus, P.O.Box \\ 2208, 71003 Heraklion, Greece \\ ${ }^{2}$ Institute of Environmental Physics and Remote Sensing, IUP, University of Bremen, Germany \\ ${ }^{3}$ Laboratoire des Sciences du Climat et de l'Environnement (LSCE), CNRS-CEA, 91191 Gif-sur-Yvette, France \\ ${ }^{4}$ Max Planck Institute for Chemistry, Mainz, Germany \\ ${ }^{5}$ Department of Chemistry and Biochemistry, University of Colorado, Boulder, Colorado, USA \\ *now at: NASA Goddard Institute for Space Studies, New York, NY 10025, USA
}

Received: 4 December 2007 - Published in Atmos. Chem. Phys. Discuss.: 31 January 2008

Revised: 13 June 2008 - Accepted: 25 July 2008 - Published: 28 August 2008

\begin{abstract}
Glyoxal, the smallest dicarbonyl, which has recently been observed from space, is expected to provide indications on volatile organic compounds (VOC) oxidation and secondary aerosol formation in the troposphere. Glyoxal (CHOCHO) is known to be mostly of natural origin and is produced during biogenic VOC oxidation. However, a number of anthropogenically emitted hydrocarbons, like acetylene and aromatics, have been positively identified as $\mathrm{CHOCHO}$ precursors. The present study investigates the contribution of pollution to the CHOCHO levels by taking into account the secondary chemical formation of $\mathrm{CHOCHO}$ from precursors emitted from biogenic, anthropogenic and biomass burning sources. The impact of potential primary land emissions of $\mathrm{CHOCHO}$ is also investigated. A global 3-dimensional chemistry transport model of the troposphere (TM4-ECPL) able to simulate the gas phase chemistry coupled with all major aerosol components is used.

The secondary anthropogenic contribution from fossil fuel and industrial VOCs emissions oxidation to the $\mathrm{CHOCHO}$ columns is found to reach $20-70 \%$ in the industrialized areas of the Northern Hemisphere and $3-20 \%$ in the tropics. This secondary $\mathrm{CHOCHO}$ source is on average three times larger than that from oxidation of VOCs from biomass burning sources. The chemical production of $\mathrm{CHOCHO}$ is calculated to equal to about $56 \mathrm{Tg} \mathrm{y}^{-1}$ with $70 \%$ being produced from biogenic hydrocarbons oxidation, $17 \%$ from acetylene, $11 \%$
\end{abstract}

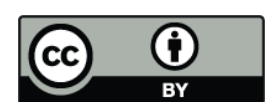

Correspondence to: M. Kanakidou (mariak@chemistry.uoc.gr) from aromatic chemistry and $2 \%$ from ethene and propene. $\mathrm{CHOCHO}$ is destroyed in the troposphere primarily by reaction with $\mathrm{OH}$ radicals $(23 \%)$ and by photolysis $(63 \%)$, but it is also removed from the atmosphere through wet $(8 \%)$ and dry deposition $(6 \%)$. Potential formation of secondary organic aerosol through $\mathrm{CHOCHO}$ losses on/in aerosols and clouds is neglected here due to the significant uncertainties associated with the underlying chemistry. The global annual mean $\mathrm{CHOCHO}$ burden and lifetime in the model domain are estimated to be $0.02 \mathrm{Tg}$ (equal to the global burden seen by SCIAMACHY over land for the year 2005) and about $3 \mathrm{~h}$, respectively. The model results are compared with satellite observations of CHOCHO columns. When accounting only for the secondary sources of $\mathrm{CHOCHO}$ in the model, the model underestimates $\mathrm{CHOCHO}$ columns observed by satellites. This is attributed to an overestimate of $\mathrm{CHOCHO}$ sinks or a missing global source of about $20 \mathrm{Tg}^{-1}$. Using the current primary emissions of $\mathrm{CHOCHO}$ from biomass burning together with the anthropogenic combustion sources of about $7 \mathrm{Tg}^{-1}$ leads to an overestimate by the model over hot spot areas.

\section{Introduction}

In the presence of nitrogen oxides $\left(\mathrm{NO}_{\mathrm{x}}=\mathrm{sum}\right.$ of nitrogen oxide, $\mathrm{NO}$, and nitrogen dioxide, $\mathrm{NO}_{2}$ ), the photochemical degradation of volatile organic compounds (VOCs) leads to secondary gaseous and particulate products, such as ozone $\left(\mathrm{O}_{3}\right)$ and secondary organic aerosols (SOA) that are

Published by Copernicus Publications on behalf of the European Geosciences Union. 
important contributors to the "photochemical smog" (see e.g. Poisson et al., 2000; Kanakidou et al., 2005). Air pollution has severe negative effects on human health (Evans et al., 2002; Pope and Dockery, 2006), ecosystems (Gregg et al., 2003) and regional climate (Ramanathan and Crutzen, 2003). The improvement of our understanding of air quality in urban areas requires a detailed knowledge of the sources, sinks and distributions of the all pollutants including VOCs. There are a large number of VOC compounds and their degradation in the troposphere is complex. However, relatively small molecules, such as formaldehyde (HCHO), methylvinylketone (MVK) and $\mathrm{O}_{3}$ are formed during the degradation of many VOC. The amounts and distribution of these gases are determined by both anthropogenic and natural emissions and can be measured in the troposphere.

Recent studies have shown that glyoxal ( $\mathrm{CHOCHO})$, the simplest alpha dicarbonyl organic compound, is one of the most prevalent dicarbonyls in the atmosphere. The main primary sources of glyoxal result from biofuel burning (Hays et al., 2002) and vehicle emissions (Kean et al., 2001; Grosjean et al. 2001), but our knowledge of these sources is highly uncertain due to the large variability of emission factors and the scarcity of the available observations. Rates of CHO$\mathrm{CHO}$ emissions from biofuel burning have been reported to be 2 to 5 times higher than those of HCHO (Hays et al., 2002). During the MCMA-2003 campaign in Mexico City, time-resolved direct observations of $\mathrm{CHOCHO}$ showed no accumulation of $\mathrm{CHOCHO}$ during rush-hour, but a fast rise in $\mathrm{CHOCHO}$ concentrations after the onset of photochemical activity, indicating that ambient $\mathrm{CHOCHO}$ is dominated by VOC photochemical sources. Recent studies have demonstrated that glyoxal is a useful indicator molecule for VOC oxidation processes (Volkamer et al., 2005b).

$\mathrm{CHOCHO}$ is produced via the oxidation of $\mathrm{C}_{n}$ hydrocarbons, where $n \geq 2$ (Calvert et al. 2000; Calvert et al. 2002), emitted as a result of anthropogenic activity, biogenic processes and biomass burning sources. It is a first generation product of acetylene oxidation by hydroxyl radical $(\mathrm{OH})$ and is produced from the oxidation of a number of other unsaturated VOCs by $\mathrm{O}_{3}$ and $\mathrm{OH}$, including ethene, $\mathrm{C}_{2} \mathrm{H}_{4}$, and isoprene, $\mathrm{CH}_{2}=\mathrm{C}\left(\mathrm{CH}_{3}\right) \mathrm{CH}=\mathrm{CH}_{2}$ (for a compilation of glyoxal precursor VOCs see Volkamer et al., 2005a, and Volkamer et al., 2007, and references therein). Similarly $\mathrm{CHOCHO}$ has been identified as a first generation product of the aromatic ring-opening routes during the $\mathrm{OH}$ radical initiated oxidation of aromatic hydrocarbons (Volkamer et al., 2001, and references therein). The secondary production of $\mathrm{CHOCHO}$ from the atmospheric degradation of furanones, unsaturated $\gamma$-dicarbonyls and phenols has been observed to be negligible (Volkamer et al., 2001; Bloss et al., 2005). The CHOCHO formation from isoprene, globally the largest source for secondary $\mathrm{CHOCHO}$, mostly proceeds via the further oxidation of the intermediates like glycolaldehyde and $\mathrm{C}_{5}$-hydroxycarbonyls (Saunders et al., 2003), which are generated in the oxidation of isoprene.
$\mathrm{CHOCHO}$ has also been detected in atmospheric aerosols (Kawamura et al., 1996; Matsunaga et al., 2003; Liggio and McLaren, 2003; Garcia-Alonso et al., 2006). It has been suggested that $\mathrm{CHOCHO}$ is strongly involved in the formation of secondary organic aerosol, SOA, in the troposphere by participating in heterogeneous reactions that form organic sulfate compounds (Liggio et al., 2005a). CHOCHO is more reactive with respect to hydration, polymerization and acetal/hemiacetal formation in the presence of alcohols than most other aldehydes (Jang and Kamens, 2001). Based on kinetic studies by Liggio et al. (2005b), the amount of SOA potentially formed by $\mathrm{CHOCHO}$ could be large enough to account for a significant part of the missing SOA in the low and free troposphere currently not reproduced by models (Heald et al., 2005; Volkamer et al., 2006a). Laboratory measurements consistently find evidence for SOA formation from CHOCHO (Liggio et al., 2005a; 2005b; Kroll et al., 2005) but are inconclusive as to the atmospheric relevance as a SOA source. Recent first field evidence of a missing $\mathrm{CHOCHO}$ sink is consistent with the upper values of SOA formation from CHOCHO (Volkamer et al., 2007) and supports the atmospheric relevance of this process.

$\mathrm{CHOCHO}$ absorbs in the UV and visible spectral range between 200 and $470 \mathrm{~nm}$ with two strong absorption features: a broad UV band between 220 and $350 \mathrm{~nm}$ and a more structured band between 350 and $470 \mathrm{~nm}$ (Atkinson et al., 2006 and references therein). The spectrum between 425 and $457 \mathrm{~nm}$ includes a sharp peak of CHOCHO at $455 \mathrm{~nm}$ (Volkamer et al., 2005c) and several minor features. These structures have been used in the recent direct detection of CHOCHO at local scales (Volkamer et al., 2005b; Sinreich et al., 2007) and global scales (Wittrock et al., 2006) from the measurements of the SCIAMACHY satellite instrument using the well established Differential Optical Absorption Spectroscopy (DOAS) technique.

Simultaneous observations of $\mathrm{HCHO}, \mathrm{CHOCHO}$, carbon monoxide $(\mathrm{CO})$ and $\mathrm{NO}_{2}$ have been proposed to provide insight to the contribution of photochemistry versus that of primary sources to the building up of pollutants in the troposphere (Garcia-Alonso et al., 2006). HCHO, which has previously been used as an indicator of VOC oxidation (Palmer et al., 2003; Wittrock et al., 2006), is produced in the oxidation of methane and other VOC. However, over urban hot spot areas, HCHO levels are determined by both direct emissions and photochemical oxidation of VOCs. Observations show that the ambient levels of $\mathrm{CHOCHO}$ are about 10 times less affected by primary sources than HCHO (as argued in Volkamer et al., 2005b). CHOCHO is therefore a valuable indicator of VOC oxidation processes (Volkamer et al., 2005b) and particularly of fast photochemistry of anthropogenic VOCs (Spaulding et al., 2003). CO is a tracer of primary anthropogenic emissions (Garcia-Alonso et al., 2006). Garcia et al. (2006) used the CHOCHO-CO tracer pair for source apportionment of ambient $\mathrm{HCHO}$ and found that 40$70 \%$ (depending on the time of day) of the ambient $\mathrm{HCHO}$ 
was emission-related in Mexico City. Furthermore, the ratio of $\mathrm{CHOCHO}$ to $\mathrm{NO}_{2}$ provides insight into the photochemical age of the studied air mass since it is increasing with air mass age and conversion of $\mathrm{NO}_{2}$ to nitric acid that is further removed from the atmosphere (Volkamer et al., 2005b; Sinreich et al., 2007).

In the present study, a global 3-dimensional chemistry transport model of the troposphere TM4-ECPL is used in order to investigate $\mathrm{CHOCHO}$ formation from biogenic, biomass burning and anthropogenic precursors and its seasonal variability. The model results are compared with satellite observations from the SCIAMACHY instrument taken in 2005. A potential primary anthropogenic source of CHO$\mathrm{CHO}$ is also investigated. Finally, the utility of synergistic use of CHOCHO and other short-lived trace gases observations from space to distinguish between the impact of anthropogenic and of natural emissions on tropospheric chemistry is examined.

\section{Model description}

The model used for the present study is the well documented off-line chemical model TM4 (Noije et al., 2004, 2006). TM4 has been evaluated in the frame of some intercomparison exercises (Shindell et al., 2006; Stevenson et al., 2006). It has 31 vertical hybrid layers from the surface to $10 \mathrm{hPa}$ and can run in two different horizontal resolutions, the low resolution of $6^{\circ} \times 4^{\circ}$ in longitude and latitude and the high resolution of $3^{\circ} \times 2^{\circ}$. For the present study, the low resolution version of the model has been used mainly for the source apportionment analysis. The basic simulation has been also performed with the high resolution version TM4-ECPL to investigate the impact of grid size on the calculated $\mathrm{CHOCHO}$ columns. The model's input meteorology comes from the ECMWF operational data for 2005 and is updated every $6 \mathrm{~h}$.

\subsection{Emissions}

The adopted emissions of primary particles (carbonaceous aerosols, dust, sea-salt, small fraction of sulfate) in TM4ECPL are presented in detail by Tsigaridis et al. (2006) and Tsigaridis and Kanakidou (2007). For the biogenic VOC emissions TM4-ECPL uses the $1^{\circ} \times 1^{\circ}$ gridded emission distribution from the POET database (Granier et al., 2005) that is based on the GEIA (Guenther et al., 1995) inventory. For the anthropogenic $\mathrm{VOC}, \mathrm{NO}_{\mathrm{x}}$ and $\mathrm{CO}$ emissions, TM4-ECPL also uses the POET emission database. This corresponds to the year 2000 that is the most recent year with complete information available. The POET dataset is derived from the Emission Database for Global Atmospheric Research (EDGAR) version 3 inventories for the anthropogenic emissions for the year 1995 with appropriate modifications to refer to recent years (Olivier et al., 2003; Granier et al., 2005). As a result of differences in the rep- resentation of the VOC chemistry in TM4-ECPL used for this study compared to the earlier studies by Tsigaridis and coworkers, TM4-ECPL uses a different speciation in the VOC emissions. The present study considers annual biogenic VOC emissions of $501 \mathrm{Tg}$ of isoprene $(1 \mathrm{Tg}$ from the oceans) and $244 \mathrm{Tg}$ of monoterpenes and Other Reactive Volatile Organic Compounds (ORVOC) that are able to produce aerosols, such as sesquiterpenes, terpenoid alcohols etc, as discussed in Griffin et al. (1999) and incorporated in the model as explained in Kanakidou et al. (2000). Additional biogenic emissions of oxygenated organics not considered as aerosol precursors are those of acetone, $\mathrm{CH}_{3} \mathrm{COCH}_{3}$, methanol, $\mathrm{CH}_{3} \mathrm{OH}$, acetaldehyde, $\mathrm{CH}_{3} \mathrm{CHO}$, and other light carbonyls (27 $\mathrm{Tg} \mathrm{y}^{-1}, 243 \mathrm{Tg} \mathrm{y}^{-1}, 2 \mathrm{Tg} \mathrm{y}^{-1}$ and $14 \mathrm{Tg} \mathrm{y}^{-1}$, respectively), which are also taken into account in the model. $\mathrm{HCHO}$ emissions from biomass burning and anthropogenic activities of $2.5 \mathrm{Tg} \mathrm{y}^{-1}$ and $1.3 \mathrm{Tg} \mathrm{y}^{-1}$, respectively, are also considered (POET database). The impact of potentially significant anthropogenic primary sources of $\mathrm{CHOCHO}$ on its tropospheric column amounts has been investigated in one simulation that considers biomass burning and other anthropogenic combustion primary $\mathrm{CHOCHO}$ emissions to be 4.8 and $2.5 \mathrm{Tg} \mathrm{y}^{-1}$ respectively, i.e. almost 2 times (within the range given by Hays et al., 2002) higher than those of HCHO. The adopted emissions of aromatic hydrocarbons (POET dataset) total $33 \mathrm{Tg} \mathrm{y}^{-1}$ with about $7 \%$ emitted from biomass burning, and in TM4-ECPL consist of $7 \mathrm{Tg} \mathrm{y}^{-1}$ of benzene, $14 \mathrm{Tg} \mathrm{y}^{-1}$ of toluene and $12 \mathrm{Tg} \mathrm{y}^{-1}$ of xylene. Among the other compounds of interest for the present study, ethene, propene and acetylene emissions from the same database account for $17 \mathrm{Tg}^{-1}, 7 \mathrm{Tg}^{-1}$ and $7 \mathrm{Tg}^{-1}$, respectively. A table with the global annual emissions used in TM4-ECPL for the present study is given in the Supplementary material http://www.atmos-chem-phys.net/8/4965/ 2008/acp-8-4965-2008-supplement.pdf.

\subsection{Chemistry}

The model considers sulphur, ammonia and $\mathrm{C}_{1}-\mathrm{C}_{5}$ hydrocarbon chemistry including isoprene, as well as highly simplified terpenes and aromatics chemistry. It uses an updated version of the Kanakidou and Crutzen (1999) and Poisson et al. (2000) chemical mechanism suitable to simulate the chemistry of the global troposphere. Gas-phase chemistry and secondary aerosol formation are coupled and computed on-line together with all other major aerosol components (sulphate, nitrate, ammonium, carbonaceous, dust, sea-salt, aerosol water). For the present simulations, dust and sea-salt components have been neglected in order to save computing time. The VOC scheme explicitly considers methane, ethane, ethene, acetylene, propane, propene, butane and isoprene. Reactions of monoterpenes and aromatics are affecting both gas-phase chemistry and aerosol production as described in Tsigaridis and Kanakidou (2003, 2007). Monoterpenes and ORVOC are represented by $\alpha$ - and $\beta$-pinene, while 
Table 1. Reactions taken into account in the TM4-ECPL model and describing CHOCHO production and destruction and the references for the rate coefficients, $k$, used in the model.

\begin{tabular}{|c|c|c|c|}
\hline $\begin{array}{l}\text { a) } \\
\text { Number }\end{array}$ & Reactions (Gas phase chemical production) & $k$ & Reference \\
\hline 1 & Isoprene $+\mathrm{OH} \rightarrow 0.03 \mathrm{CHOCHO}+$ products & $2.7 \mathrm{E}-11 \exp (390 / T)$ & IUPAC (2006) \\
\hline 2 & $\mathrm{C}_{2} \mathrm{H}_{4}+\mathrm{O}_{3}+2 \mathrm{O}_{2} \rightarrow 0.0044 \mathrm{CHOCHO}+$ products & $9.1 \mathrm{E}-15 \exp (-2580 / T)$ & IUPAC (2006) \\
\hline 3 & $\mathrm{C}_{3} \mathrm{H}_{6}+\mathrm{O}_{3}+2 \mathrm{O}_{2} \rightarrow 0.05 \mathrm{CHOCHO}+$ products & $5.5 \mathrm{E}-15 \exp (-1880 / T)$ & IUPAC (2006) \\
\hline 4 & $\mathrm{C}_{2} \mathrm{H}_{2}+\mathrm{OH} \rightarrow 0.635 \mathrm{CHOCHO}+$ products & 3 bodies reaction & IUPAC (2006) \\
\hline 5 & Benzene $+\mathrm{OH} \rightarrow 0.36 \mathrm{CHOCHO}+$ products & $2.47 \mathrm{E}-12 \exp (207.0 / \mathrm{T})$ & Calvert et al. (2002) \\
\hline 6 & Toluene $+\mathrm{OH} \rightarrow 0.306 \mathrm{CHOCHO}+$ products & $5.96 \mathrm{E}-12$ & Atkinson (1994) \\
\hline 7 & 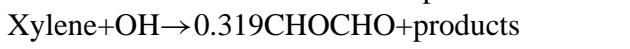 & $1.72 \mathrm{E}-11$ & Average of ortho-, meta-, para-isomers \\
\hline 8 & $\mathrm{HOCH}_{2} \mathrm{CHO}+\mathrm{OH}+\mathrm{O}_{2} \rightarrow \mathrm{CHOCHO}+\mathrm{HO}_{2}+\mathrm{H}_{2} \mathrm{O}$ & $2.2 \mathrm{E}-12$ & IUPAC (2006) \\
\hline \multicolumn{4}{|l|}{ b) } \\
\hline Number & Reactions (Gas phase chemical destruction) & $k$ & Reference \\
\hline 1 & $\mathrm{CHOCHO}+\mathrm{OH} \rightarrow 2 \mathrm{CO}+\mathrm{HO}_{2}+\mathrm{H}_{2} \mathrm{O}$ & $2.8 \times 10^{-12} \exp (340 / \mathrm{T})$ & Feierabend et al. (2008) \\
\hline 2 & $\mathrm{CHOCHO}+\mathrm{NO}_{3}+\mathrm{O}_{2} \rightarrow \mathrm{HNO}_{3}+\mathrm{HO}_{2}+2 \mathrm{CO}$ & $1.2 \mathrm{E}-15$ & $\begin{array}{l}\text { upper limit estimate by I. Barnes } \\
\text { (personal communication, 2007) }\end{array}$ \\
\hline 3 & $\mathrm{CHOCHO}+h v \rightarrow 2 \mathrm{HO}_{2}+2 \mathrm{CO}$ & $J_{\mathrm{CHOCHO}}$ & IUPAC (2006) \\
\hline
\end{tabular}

aromatic compounds are represented by benzene, toluene and xylene. The $\alpha$ - and $\beta$-pinene oxidation by hydroxyl $(\mathrm{OH})$ and nitrate $\left(\mathrm{NO}_{3}\right)$ radicals and ozone are considered to form semi-volatile organics, which are the precursors of $\mathrm{SOA}$, and $\mathrm{C}_{5}$ peroxy radicals, like the first generation peroxy radicals from isoprene oxidation. The reactions of all peroxy radicals with hydrogen peroxide $\left(\mathrm{HO}_{2}\right)$ and methyl peroxide $\left(\mathrm{CH}_{3} \mathrm{O}_{2}\right)$ are taken into account as indicated in Vrekoussis et al. (2004) with updated kinetics based on Atkinson et al. (2006). $\mathrm{NO}_{3}$ radical reactions with aldehydes, alcohols, dimethylsulfide, $\mathrm{CH}_{3} \mathrm{SCH}_{3}$ (DMS), butane, $\mathrm{C}_{4} \mathrm{H}_{10}$, and unsaturated hydrocarbons are considered. Aromatics are considered to react with $\mathrm{OH}, \mathrm{O}_{3}$ and $\mathrm{NO}_{3}$, with the reaction of $\mathrm{OH}$ being the dominant removal process accounting for $100,99.9,99.8 \%$ of the removal of benzene, toluene and xylene, respectively. The reactions of aromatics with $\mathrm{OH}$ produce $\mathrm{CHOCHO}$ as a first generation product and peroxy radicals that can further react to form gaseous and aerosol products. For simplicity purposes, their gaseous products are treated in the model as butyloperoxy radicals and attention is paid to preserve the carbon balance. SOA production by VOC oxidation is parameterized as detailed in Tsigaridis and Kanakidou (2003). The full list of chemical reactions and reaction rates adopted in TM4-ECPL is given in the Supplementary material http://www.atmos-chem-phys.net/8/4965/ 2008/acp-8-4965-2008-supplement.pdf.

For CHOCHO, the TM4-ECPL model considers primary formation during the oxidation of isoprene, acetylene, aromatic hydrocarbons (Volkamer et al., 2005a) and ozonolysis of ethene and propene as well as secondary formation (via glycolaldehyde $-\mathrm{HOCH}_{2} \mathrm{CHO}$ ) from the oxidation of ethene and from peroxy radicals produced during the oxida- tion of isoprene (Table 1). Other biogenic hydrocarbons, like terpenes, and other reactive organics, like sesquiterpenes, and terpenoid alcohols also produce $\mathrm{CHOCHO}$ (as secondary product) in TM4-ECPL, since their chemistry is lumped on the first generation peroxy radicals of isoprene (as parameterized in Tsigaridis and Kanakidou, 2003). CHOCHO is destroyed by photolysis (Volkamer et al., 2005c; Atkinson et al., 2006; Tadic et al., 2006), reaction with $\mathrm{OH}$ (Feierabend et al., 2008) and to a lesser extent with $\mathrm{NO}_{3}$, and removed via wet and dry deposition. For the dry deposition of $\mathrm{CHOCHO}$ as for the other gaseous species, the Ganzeveld and Lelieveld (1995) resistance-in-series scheme has been used, which is based on the formulation developed by Wesely (1989). For the wet deposition, both large scale and convective precipitation are considered and the in-cloud and below cloud scavenging are parameterised in the model TM4ECPL as described in detail by Jeuken et al. (2001). Incloud scavenging of $\mathrm{CHOCHO}$ is parameterized based on the Henry's law coefficient of $K_{H}=2.610^{7} M \cdot \mathrm{atm}^{-1}$ (Kroll et al., 2005) that is 2 orders of magnitude higher than the Henry's Law coefficient suggested by Lim et al. (2005). The in-cloud loss of CHOCHO has been suggested to be a significant sink for glyoxal leading to SOA formation (Liggio et al., 2005; Loeffler et al., 2006; Sorooshian et al., 2007). The importance of this process for SOA budget in the global troposphere requires further investigation by targeted 3-dimensional simulations.

\subsection{The simulations}

In order to investigate the influence of natural and anthropogenic emissions of hydrocarbons on $\mathrm{CHOCHO}$ 
distribution and its global budget, several different CHOCHO-chemistry scenarios have been considered. The first simulation (S1) accounts for $\mathrm{CHOCHO}$ production only from the oxidation of the naturally emitted VOCs. S1 also considers in-cloud loss of $\mathrm{CHOCHO}$ as explained in Sect. 2.2. The second simulation (S2) is the same as that for S1 but also takes into account the contribution of biomass burning emissions of ethene, propene, acetylene and aromatics to the chemical production of CHOCHO. The third simulation ( $\mathrm{S} 3$, used as the base case for the present study) is as (S2) but considers in addition the contribution of anthropogenic emissions of ethene, propene, acetylene and aromatics to $\mathrm{CHOCHO}$ formation, i.e. accounts for all known photochemical sources of glyoxal. This simulation has also been performed at the high horizontal resolution of TM4-ECPL (S3-H). The difference between the simulations (S2) and (S1) is attributed to the secondary production of glyoxal from the biomass burning VOCs; whereas that between (S3) and (S2) is attributed to the production of glyoxal from anthropogenic VOC. Despite the significant variability in the primary CHO$\mathrm{CHO}$ emission factors and the scarcity of available data, the possible impact of significant primary sources of $\mathrm{CHOCHO}$ on its tropospheric columns has been investigated in an additional simulation (S4) that considers such emissions from biomass burning as well as from anthropogenic combustion sources proportional to those of HCHO (see also Sect. 2.1). Finally, the impact of the assumption of a lower Henry's law coefficient $\left(K_{H}\right)$ for CHOCHO wet removal on its tropospheric burden has been investigated by an additional simulation (S5) that uses a 100 times lower $K_{H}$ than the other simulations.

When compared with our earlier work (Wittrock et al., 2006), simulation S3 of the present study i) uses updated anthropogenic and biomass burning emission inventories based on the POET database for the year 2000 and about $20 \%$ higher isoprene emissions of $500 \mathrm{Tg} \mathrm{yr}^{-1}$, which are within the range of the present-day estimates by Guenther et al. (2006), ii) takes into account the formation of CHO$\mathrm{CHO}$ from ethene, propene, acetylene and aromatics that are predominantly of anthropogenic origin but have also a minor natural component, iii) takes into account the temperature dependence of the reaction of $\mathrm{CHOCHO}$ with $\mathrm{OH}$ radicals (Feierabend et al., 2008), and iv) calculates on line as described by Landgraf and Crutzen (1998) and Lelieveld et al. (2002) the photolysis rates of CHOCHO based on the IUPAC and JPL recommendations (Atkinson et al., 2006 and references therein; Sander et al., 2006). Moreover, Wittrock et al. (2006) used diurnal mean CHOCHO columns to compare with the satellite observations whereas in the present study the columns calculated for the satellite overpass time have been used (10-11 a.m. local time).

\section{Satellite observations}

\subsection{The instrument}

The sensor SCIAMACHY (SCanning Imaging Absorption spectroMeter for Atmospheric CartograpHY) is mounted on the ESA ENVISAT satellite. It is designed to measure sunlight transmitted, reflected and scattered by the earth's atmosphere or surface in the ultraviolet, visible and near infrared (Burrows et al., 1995; Bovensmann et al., 1999). The sun-synchronous, near polar orbit of the satellite has a local equator crossing time of $10 \mathrm{a} . \mathrm{m}$. in the descending node. The alternative measurements of nadir and limb viewing geometries (Gottwald et al., 2006) are coupled with a swath width of $960 \mathrm{~km}$ and global coverage is achieved within six days. The ground pixel size used in this study is $30 \mathrm{~km}$ along track by $60 \mathrm{~km}$ across track.

\subsection{The retrieval technique and $\mathrm{CHOCHO}$ algorithm}

The retrieval approach adopted for the vertical columns of $\mathrm{CHOCHO}$ is based on the well established DOAS technique. Briefly, DOAS is used for the determination of the Slant Column densities (SCD) of the respective absorbers in a given spectral window (436-457 $\mathrm{nm}$ for the present study). Only ground scenes having less than 20 percent cloud cover are considered. The SCD is then converted to Vertical Column Densities (VCD) by applying the air mass factor (AMF), which is defined as the ratio of the SCD/VCD. This accounts for the path of light through the atmosphere and considers the vertical profiles of scattering and absorbing species (Wittrock et al., 2004). The absorption cross sections of CHOCHO (Volkamer et al., 2005c), $\mathrm{O}_{3}, \mathrm{NO}_{2}, \mathrm{H}_{2} \mathrm{O}, \mathrm{O}_{4}$, phytoplankton (Bracher and Tilzer, 2001; Vountas et al., 2007), a ring spectrum, which accounts for rotational Raman scattering, and a quadratic polynomial are included in the fitting procedure.

Prior conversion to vertical columns, the retrieved slant columns are normalised by assuming a mean value of 0.5 $10^{14}$ molecules.cm ${ }^{-2}$ for CHOCHO over the Pacific in latitudes $\left(30^{\circ} \mathrm{N}-30^{\circ} \mathrm{S}\right)$ in the region between $165^{\circ} \mathrm{E}$ and $165^{\circ} \mathrm{W}$. This normalisation is necessary for many GOME and SCIAMACHY products to compensate for offsets introduced by the solar reference measurements and interference from other absorbers (Richter and Burrows, 2002). More details on the CHOCHO analysis can be found in (Wittrock et al., 2006). For comparison with the global model, the SCIAMACHY data, which initially are gridded to $0.125^{\circ} \times 0.125^{\circ}$, have been re-gridded to the horizontal resolution of the model. This data manipulation could justify the anomalous high values of $\mathrm{CHOCHO}$ near a few ice/water borders shown in Fig. 1. 
Table 2. TM4-ECPL model calculations of CHOCHO (S3-S3H; range of seasonal values for the low and high resolution simulations; S4: seasonal mean values and standard deviation) and comparisons with ground based observations. Observations are associated with an error of at least $\pm 15 \%$.

\begin{tabular}{|c|c|c|c|c|c|c|}
\hline Location & Coordinates & Period & $\begin{array}{l}\text { Model (S3- } \\
\text { S3H) (ppbv) }\end{array}$ & $\begin{array}{l}\text { Model (S4) } \\
\text { (ppbv) }\end{array}$ & $\begin{array}{l}\text { Observations } \\
(\mathrm{ppbv})\end{array}$ & Reference \\
\hline $\begin{array}{l}\text { Pinnacles, Shenandon } \\
\text { National Park }\end{array}$ & $\begin{array}{l}36.29 \mathrm{~N} \\
121.10 \mathrm{~W}\end{array}$ & Autumn & $0.04-0.13$ & $0.06 \pm 0.01$ & 0.04 & Munger et al. (1995) \\
\hline $\begin{array}{l}\text { Georgia, } \\
\text { USA }\end{array}$ & $\begin{array}{l}32.32 \mathrm{~N} \\
82.08 \mathrm{E}\end{array}$ & Summer & $0.02-0.03$ & $0.02 \pm 0.01$ & $0.02-0.09$ & Lee et al. (1995) \\
\hline $\begin{array}{l}\text { Long Beach, Central } \\
\text { LA, Azusa, } \\
\text { Claremont, USA }\end{array}$ & $\begin{array}{l}33.4 \mathrm{~N} \\
118.11 \mathrm{~W} \\
\text { (mean) }\end{array}$ & Autumn & $0.07-0.14$ & $0.09 \pm 0.03$ & $0.78 \pm 0.85$ & Grosjean et al. (1996) \\
\hline $\begin{array}{l}\text { Porto Allegre, } \\
\text { Brazil }\end{array}$ & $\begin{array}{l}30.2 \mathrm{~S} \\
51.1 \mathrm{~W}\end{array}$ & Spring & $0.02-0.08$ & $0.02 \pm 0.01$ & 0.30 & Grosjean et al. (1999) \\
\hline $\begin{array}{l}\text { Los Angeles, } \\
\text { USA }\end{array}$ & $\begin{array}{l}34.3 \mathrm{~N} \\
118.15 \mathrm{~W}\end{array}$ & Autumn & $0.02-0.07$ & $0.09 \pm 0.03$ & $0.04-0.95$ & Kawamura et al. (2000) \\
\hline $\begin{array}{l}\text { Giesta, } \\
\text { Portugal }\end{array}$ & $\begin{array}{l}41.11 \mathrm{~N} \\
8.35 \mathrm{E}\end{array}$ & Summer & 0.01 & 0.01 & $0.52-2.42$ & Borrego et al. (2000) \\
\hline $\begin{array}{l}\text { Las Vegas, } \\
\text { USA }\end{array}$ & $\begin{array}{l}36.10 \mathrm{~N} \\
115.12 \mathrm{~W}\end{array}$ & $\begin{array}{l}\text { Summer } \\
\text { Winter }\end{array}$ & $\begin{array}{l}0.11-0.17 \\
0.02-0.11\end{array}$ & $\begin{array}{l}0.18 \pm 0.5 \\
0.14 \pm 0.01\end{array}$ & $\begin{array}{l}0.12-0.42 \\
0.09-0.21\end{array}$ & Jing et al. (2001) \\
\hline $\begin{array}{l}\text { Hong Kong, } \\
\text { China }\end{array}$ & $\begin{array}{l}22.18 \mathrm{~N} \\
114.1 \mathrm{E}\end{array}$ & Winter & $0.05-0.06$ & $0.09 \pm 0.03$ & $\begin{array}{l}19.70-28.0 \\
8.40-23.7 \\
8.60-11.9 \\
8.80-14.8\end{array}$ & Ho and $\mathrm{Yu}(2002)$ \\
\hline $\begin{array}{l}\text { Pabsthum (near } \\
\text { Berlin), Germany }\end{array}$ & $\begin{array}{l}52.51 \mathrm{~N} \\
12.56 \mathrm{E}\end{array}$ & Summer & $0.18 \pm 0.03$ & $0.17 \pm 0.03$ & $0.01-0.12$ & Moortgat et al. (2002) \\
\hline Mexico City, Mexico & $\begin{array}{l}19.24 \mathrm{~N} \\
99.12 \mathrm{~W}\end{array}$ & Spring & $0.21-0.41$ & $0.35 \pm 0.13$ & $0.15-1.82$ & Volkamer et al. (2005) \\
\hline $\begin{array}{l}\text { MIT, } \\
\text { USA }\end{array}$ & $\begin{array}{l}42.36 \mathrm{~N} \\
71.09 \mathrm{~W}\end{array}$ & Summer & $0.19-0.41$ & $0.18 \pm 0.03$ & $0.04-0.14$ & Sinreich et al. (2007) \\
\hline $\begin{array}{l}\text { ICARTT } 2004 \\
\text { RV Ron Brown }\end{array}$ & $\begin{array}{l}43 \mathrm{~N} \\
68 \mathrm{~W}\end{array}$ & Summer & $0.14-0.19$ & $0.18 \pm 0.03$ & $0.10-0.35$ & Sinreich et al. (2007) \\
\hline
\end{tabular}

\section{Results and discussion}

\subsection{Comparison of CHOCHO from model and surface ob-} servations

Even at its high spatial resolution of $2^{\circ}$ latitude and $3^{\circ}$ longitude, TM4-ECPL has a rather coarse grid that at $45^{\circ} \mathrm{N}$ corresponds to about $220 \mathrm{~km}$ in latitude $\times 230 \mathrm{~km}$ in longitude. Therefore, it is expected that as most global models, TM4ECPL underestimates short lived species concentrations over hot spot areas. This is because these hot spot areas extend only over a small fraction of the surface of the model grid boxes and thus in these model grids the short lived species are artificially diluted over hot spot areas by instantaneous mixing with cleaner air from the surrounding locations in the same grid boxes. Keeping in mind these limitations, the re- sults of the high resolution TM4 simulation (S3-H) are evaluated by comparison with ground based observations reported in the literature for different places of the world (Table 2). An overall reasonable agreement is seen between the TM4ECPL S3-H simulated boundary layer CHOCHO concentrations and the surface observations. The model reproduces well the observations by Sinreich et al. (2007) at coastal oceanic areas on board the RV Ron Brown. In contrast, it misses the extremely high values observed inside the urban core of Hong Kong by Ho and Yu (2002).

In addition to the above mentioned spatial effects that contribute to the differences between model results and observations, uncertainties in oxidant fields, VOC loadings and particulate matter levels are also at the origin of differences illustrated in Table 2. The use of emission inventories for the year 2000 to simulate the year 2005 can also cause some 
discrepancies. In addition, potentially existent primary $\mathrm{CHO}-$ CHO sources that have been neglected in TM4-ECPL (as discussed in Sect. 2.3) could be a reason for an underestimate of CHOCHO levels by simulation S3. However, results from the simulation $\mathrm{S} 4$ that accounts for some potential primary sources of CHOCHO are also reported in Table 2 and indicate only minor improvement in the model comparisons with surface observations. On the other hand, a potentially strong missing sink of $\mathrm{CHOCHO}$ could explain an overestimate of CHOCHO in the model. Such a sink of CHOCHO on aerosols has been suggested by Volkamer et al. (2007) to reconcile glyoxal observations in Mexico City with results of a box model that was very well experimentally constrained.

It has to be stressed that there is a clear need for more ground based CHOCHO observations available for model and satellite evaluations, in particular over oceanic areas since most of the $\mathrm{CHOCHO}$ observations are restricted to continental anthropogenically influenced locations.

\subsection{Annual mean $\mathrm{CHOCHO}$ columns}

Focusing on the global annual mean CHOCHO column distribution for the year 2005, the S3-H simulations are compared with the columns retrieved from SCIAMACHY measurements in Fig. 1. The model (Fig. 1a) captures high columns of $\mathrm{CHOCHO}$ in the tropics associated mainly with biogenic and biomass burning emissions, in agreement with the retrievals based on SCIAMACHY measurements (Fig. 1b), although the model underestimates the observations.

As seen in the figures, the current version of TM4-ECPL does not reproduce the significant amounts of $\mathrm{CHOCHO}$ retrieved from SCIAMACHY measurements over the tropical oceans close to upwelling areas neither at high latitudes in regions of primary productivity. For quantitative analysis, the simulated annual mean $\mathrm{CHOCHO}$ vertical columns have been plotted against the SCIAMACHY annual mean observations in 2005 for all grid boxes with SCIAMACHY observations (Fig. 1c). To reduce the variability of the data, the modeled $\mathrm{CHOCHO}$ columns were grouped (binned) into values of $0.2510^{14}$ molecules $\mathrm{cm}^{-2}$ of SCIAMACHY observational data, independent from the exact location of these observations. Results from both high (S3-H) and low (S3) horizontal resolution simulations have been plotted. It appears that the two simulations behave similarly (no statistical difference) with regard to observations. Both these correlations correspond to linear fits with slopes of $0.43 \pm 0.07$ and correlation coefficient $r$ of 0.95 . Additional comparison of model results with observations, excluding the values over the oceans, indicate better correlation $(r=0.99)$ and slope of $0.61 \pm 0.07$. This behavior is best explained by

(a) the existence of primary or secondary tropical sources of CHOCHO over the oceans, neglected or underestimated by the current model; (b) a current underestimation of the land sources when only secondary emissions of glyoxal are taken into account by the model.

Figure $1 \mathrm{c}$ indicates that at least about $25 \%$ of the CHOCHO column is missing in the model when accounting for all data and their variability. Taking into account the global secondary source calculated by TM4-ECPL of $56 \mathrm{Tg} \mathrm{y}^{-1}$ this missing CHOCHO source corresponds to about $20 \mathrm{Tg} \mathrm{y}^{-1}$ that could be entirely or partially located over the oceans (see further discussion for the existence of primary land sources). Phytoplankton bloom areas could release significant amounts of VOC in the atmosphere (J. Williams, personal communication, 2008). Such emissions are not taken into account in the present study. Note that this discrepancy could be also attributed to an overestimate of glyoxal sinks. Compared to the earlier simulations in Wittrock et al. (2006), in the present study TM4-ECPL is able to reproduce part of the outflow from the continents (Sinreich et al., 2007) and slight enhancement over the tropical oceans and the north Atlantic that are seen by SCIAMACHY. These patterns are under investigation and can not be properly reproduced by TM4-ECPL based on the processes that are actually considered to control CHOCHO levels in the model.

Figure 1d focuses on the low resolution simulations S2, S3 and S4. Taking only the model results over the continents into consideration, the binned data, derived as explained, are plotted in Fig. 1d against the annual mean vertical column of CHOCHO derived from SCIAMACHY. S3 considers all known photochemical sources of CHOCHO. S2 neglects the anthropogenic contribution to the secondary CHO$\mathrm{CHO}$ source. Finally, S4 accounts also for potential primary sources of CHOCHO from combustion. Figure 1d suggests that i) TM4-ECPL underestimates the annual mean CHOCHO columns observed by SCIAMACHY in 2005 , ii) when accounting for the anthropogenic contribution to the photochemical formation of CHOCHO, TM4-ECPL results compare better with the observations and iii) consideration of primary anthropogenic sources of CHOCHO further improves the general agreement of model results with satellite observations over land.

Figure 1e focuses on 8 hot spot areas around the globe, including China where anthropogenic emissions increase rapidly (see figure caption for the geographic definition of the areas). It appears that i) simulation S3, considering only secondary sources of $\mathrm{CHOCHO}$, agrees with satellite observations over these areas within the $95 \%$ confidence level, although generally it underestimates the columns over land (Fig. 1d); ii) simulation S4 overestimates $\mathrm{CHOCHO}$ columns over source areas (Fig. 1e), although it seems to perform relatively well (95\% confidence level) with regard to the global burden of glyoxal over land (Fig. 1d). Both simulations S3 and S4 underestimate the surface observations as shown in Table 2. Due to the high uncertainties both in potential primary emissions of $\mathrm{CHOCHO}$ and in satellite retrievals, these 
(a)

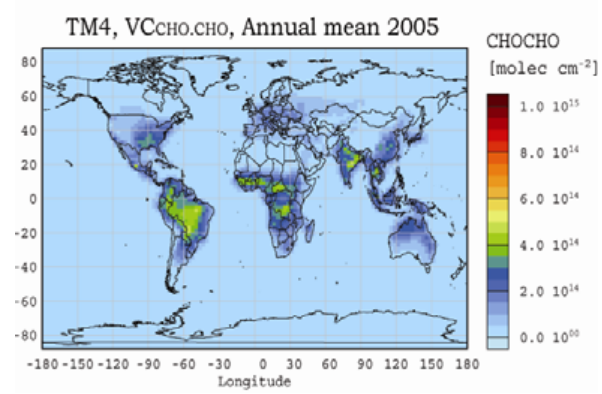

(c)

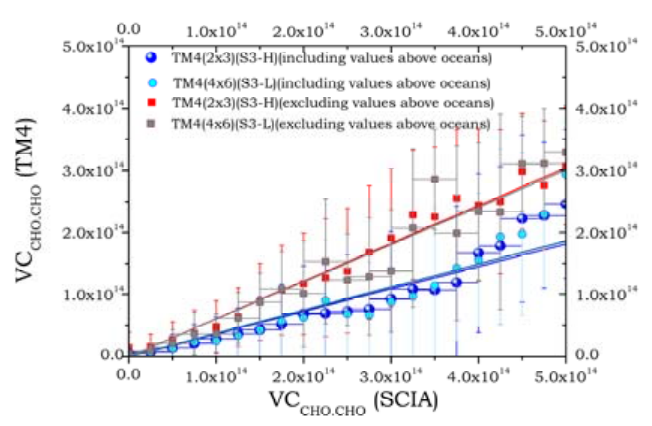

(e)

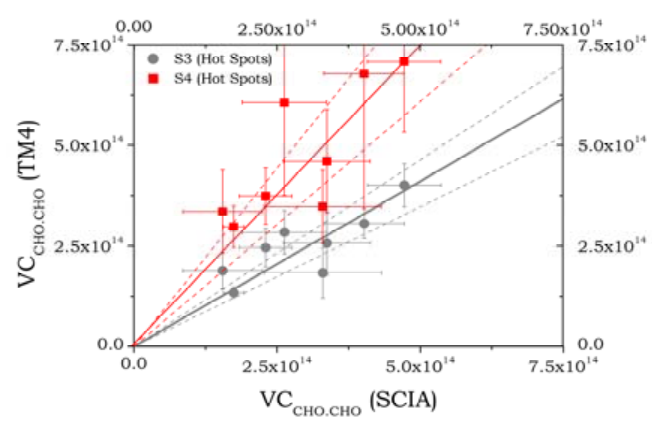

(b)

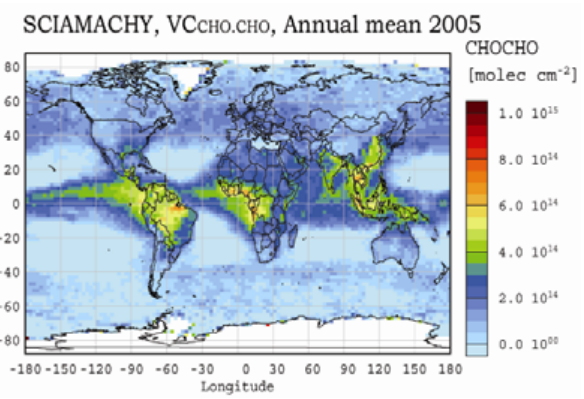

(d)

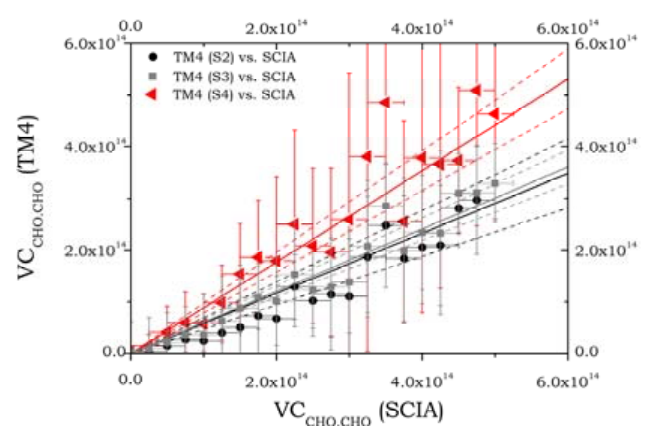

Fig. 1. Global annual mean column distribution of $\mathrm{CHOCHO}$ (in $2^{\circ} \times 3^{\circ}$ grid) for the year 2005 (in molecules $\mathrm{cm}^{-2}$ ):

(a) Simulated by TM4-ECPL, taking into account all glyoxal sources (simulation S3-H).

(b) Retrieved from the measurements made by the satellite based sensor SCIAMACHY

(c) Comparison of annual mean glyoxal columns from TM4-ECPL-S3 simulations and SCIAMACHY data product (in units of molecules $\mathrm{cm}^{-2}$ ). The points show the annual mean simulated columns for the year 2005 binned every $0.2510^{14}$ molecules cm $\mathrm{cm}^{-2}$ of the corresponding SCIAMACHY observations, together with their standard deviations. Dark blue circles and light blue are the binned data when both land and oceanic grids are considered for the TM4-ECPL-S3-H and TM4-ECPL-S3 simulations, respectively. Solid red and black squares are the corresponding binned data when neglecting the grid cells over the oceans.

(d) Comparison of annual mean glyoxal columns from TM4- ECPL simulations and SCIAMACHY data products (in units of molecules $\mathrm{cm}^{-2}$ ). Binned data over the continents; red triangles are for S4 simulation, solid gray squares for S3 simulation, and solid black circles for S2 simulation. Linear fit regression lines are also plotted with the corresponding color.

(e) Comparison of annual mean glyoxal columns from the TM4-ECPL simulations S3 (circles) and S4 (squares) with the SCIAMACHY data products (in units of molecules $\mathrm{cm}^{-2}$ ) over hot spot areas. Linear regression lines given in grey and red (and $95 \%$ confidence level interval), respectively, correspond to a slope of $0.81 \pm 0.05\left(R^{2}=0.92\right)$ for S3 and of $1.43 \pm 0.14\left(R^{2}=0.95\right)$ for S4. Hot spot areas are defined as follows: Central Europe ( $42 \mathrm{~N}: 54 \mathrm{~N} ; 6 \mathrm{E}: 24 \mathrm{E})$; NE USA (30 N:42 N; $96 \mathrm{~W}: 78 \mathrm{~W})$; Central S America (Amazon) (18 S:6 S; $66 \mathrm{~W}: 48 \mathrm{~W})$; Central N Africa (2 S:10 N; $12 \mathrm{E}: 30 \mathrm{E})$; Central S Africa (18 S:6 S; $12 \mathrm{E}: 30 \mathrm{E}) ;$ India (18 N:30 N; $72 \mathrm{E}: 90 \mathrm{E})$; China (26 N:38 N; 102 E:120 E); Australia (26 S:14 S; 120 E:138 E). 
simulations are not conclusive with regard to the magnitude of the primary $\mathrm{CHOCHO}$ source. Overestimate of $\mathrm{CHOCHO}$ sink in the model could be responsible for part of the discrepancies between model results and observations.

Figure 2a depicts the distribution of the global annual mean CHOCHO column for the year 2005, computed by the $\mathrm{S} 3$ simulation and is compared with that from the SCIAMACHY observations at the same spatial resolution $\left(4^{\circ} \times 6^{\circ}\right)$ shown in Fig. 2c. Figure $2 b$ shows the calculated annual mean column of CHOCHO produced from biogenic VOC oxidation (simulation $\mathrm{S} 1$ ). The majority of the annual mean column of $\mathrm{CHOCHO}$ over the tropics, which maximizes at around $510^{14}$ molecules $\mathrm{cm}^{-2}$, is attributed to the oxidation of biogenic VOCs. Annual mean columns smaller than $310^{14}$ molecules $\mathrm{cm}^{-2}$ are computed over the Northern Hemisphere mid-latitude continental regions. Note that these biogenically derived $\mathrm{CHOCHO}$ columns are slightly smaller than the earlier simulations presented in Wittrock et al. (2006), which did not account for the wet removal of $\mathrm{CHOCHO}$ in clouds and used a lower estimate of the photolysis rate of $\mathrm{CHOCHO}$ than the present study.

The secondary biomass burning source of $\mathrm{CHOCHO}$ from the oxidation of VOCs is taken into account in the simulations (S2 and S3) and is evaluated as the difference between the simulations S2 and S1 that is depicted in Fig. 2e (annual mean column) and Fig. 3i,j (seasonally mean columns). According to our calculations, based on current knowledge of VOCs released by biomass burning, the secondary source of $\mathrm{CHOCHO}$ from biomass burning contributes about $3 \mathrm{Tg} \mathrm{y}^{-1}$ to the global chemical production of glyoxal and therefore increases its global annual mean burden by about $5 \%$, adding at most $210^{14}$ molecules $\mathrm{cm}^{-2}$ to the CHOCHO column over tropical biomass burning areas. As mentioned in Sect. 2.3, primary emissions of $\mathrm{CHOCHO}$ from burning in the tropics (and elsewhere) have been considered only in simulation S4. Although these emissions are highly uncertain, they might be of importance for $\mathrm{CHOCHO}$ columns over source regions. The contribution of a potential primary source of CHOCHO from combustion, including biomass burning, is depicted in Fig. $2 \mathrm{f}$ and is shown to maximize over the tropics. There, primary emissions are evaluated to contribute with up to 8 $10^{14}$ molecules $\mathrm{cm}^{-2}$ to $\mathrm{CHOCHO}$ annual mean columns (Fig. 2f). Simulations S3 and S4 also calculate significant CHOCHO columns of about 2 to $610^{14}$ molecules $\mathrm{cm}^{-2}$ over hot spot regions of anthropogenic activity areas of the USA, Europe, India and China (Fig. $2 \mathrm{~d}$ and $\mathrm{f}$ ) that are also detectable from space but are not reproduced in simulations S1 and S2. Note that Fig. 2d depicts the increase in the annual mean column of $\mathrm{CHOCHO}$ accounting for $\mathrm{CHOCHO}$ production during the oxidation of anthropogenically emitted VOC (difference between simulations S3 and S2). This secondary source of $\mathrm{CHOCHO}$ from anthropogenic emissions contributes about $13 \mathrm{Tg} \mathrm{y}^{-1}$ to the global chemical production of CHOCHO, i.e. about $20 \%$ of the overall chemical production. The $\mathrm{CHOCHO}$ global annual mean burden resulting from the anthropogenic emissions is about $32 \%$ of the total; this fraction is larger than the corresponding fraction of the chemical production. This reflects the fact that the secondary anthropogenic source is located mostly in the extra-tropics where the destruction of $\mathrm{CHOCHO}$ by photolysis and reaction with $\mathrm{OH}$ radical is moderate and thus $\mathrm{CHOCHO}$ lifetime is longer than its global mean value.

On the contrary, in S3 the biogenically derived burden of $\mathrm{CHOCHO}$ is $63 \%$ of the total CHOCHO burden whereas the corresponding chemical production is higher, about $77 \%$ of the total. This increased chemical production is compensated by a shorter lifetime of $\mathrm{CHOCHO}$ in the tropics. Thus, the computed global lifetime of glyoxal averaged year-around increases from $2.4 \mathrm{~h}$ when only biogenic sources are taken into account (S1) and $2.5 \mathrm{~h}$ when biomass burning sources are also considered (S2) to $3 \mathrm{~h}$ when all secondary sources are taken into account (S3).

Our simulations indicate that the global mean lifetime of $\mathrm{CHOCHO}$ critically depends on the location of its sources. In particular, the anthropogenic sources of $\mathrm{CHOCHO}$ are more effective in increasing its burden since they are located mostly in the mid latitudes where the photochemical sink of glyoxal is moderate.

\subsection{Seasonal variation}

The seasonal patterns of the calculated and observed CHO$\mathrm{CHO}$ columns have also been compared. Figure 3 depicts the $\mathrm{NH}$ winter and $\mathrm{NH}$ summer column distributions of $\mathrm{CHO}-$ CHO as observed by SCIAMACHY (panels 3a and b, respectively) and as calculated by the TM4-ECPL S3 simulation (panels $3 \mathrm{c}$ and d, respectively). In the NH, TM4-ECPL simulations show higher $\mathrm{CHOCHO}$ columns during summer than during winter in agreement with the satellite observations, reflecting the photochemical origin of $\mathrm{CHOCHO}$ and the important contribution of the biogenic VOC oxidation to CHO$\mathrm{CHO}$ chemical production (Fig. 3e and f). It is also remarkable that during $\mathrm{NH}$ summer the model overestimates the $\mathrm{CHOCHO}$ over the Amazon, but not over the African tropical forests. Biomass burning emissions occurring mostly in the tropics have a strong seasonality with significantly different geographical patterns from one season to another. This is reflected in the CHOCHO distribution as depicted in Fig. $3 \mathrm{i}$ and $\mathrm{j}$. However, their contribution to the $\mathrm{CHOCHO}$ columns is minor compared to that from the biogenic VOC oxidation (Fig. 3e and f). The most likely explanation of the model overestimate of $\mathrm{CHOCHO}$ columns is related to the biogenic VOC emission inventory used.

Biogenic VOC emissions are enhanced under warm and sunny conditions (Guenther et al., 2006); between $30^{\circ} \mathrm{N}$ and $60^{\circ} \mathrm{N}$ are about 50 times higher during summer than during winter. On the contrary, the anthropogenic VOC emissions present a much weaker seasonality. In our model simulations this seasonality is neglected, because both the EDGAR and POET emissions database do not provide information on 
(a)

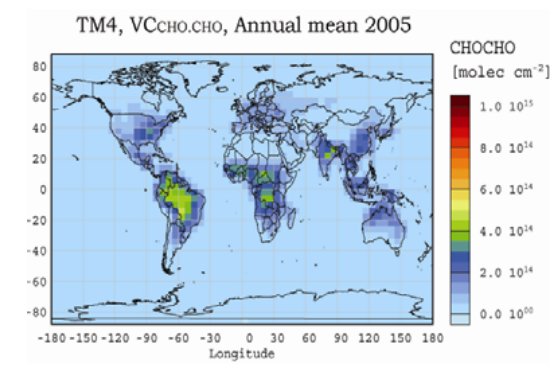

(c)

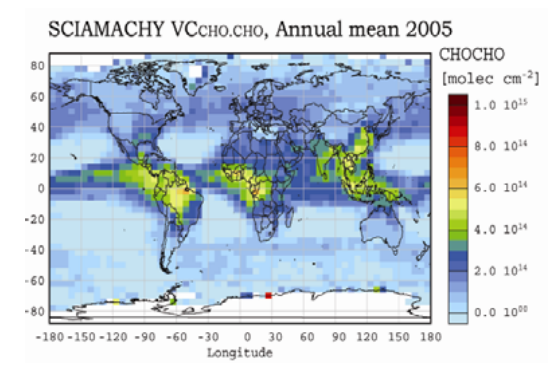

(e)

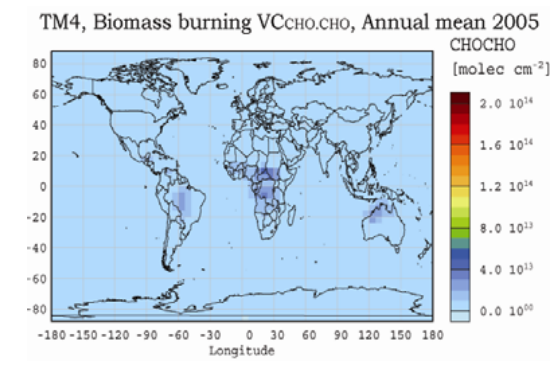

(b)

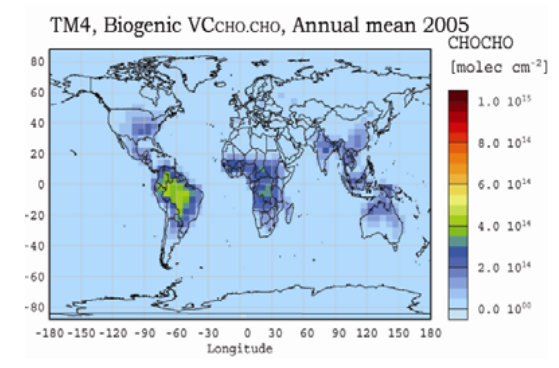

(d)

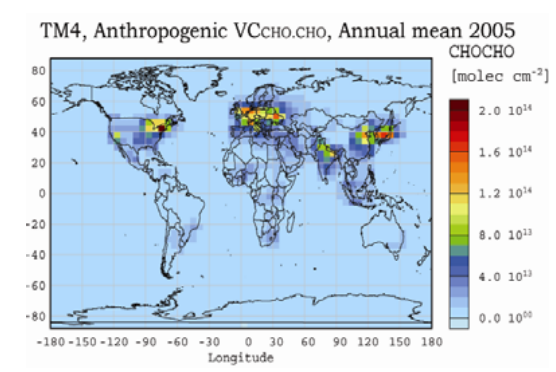

(f)

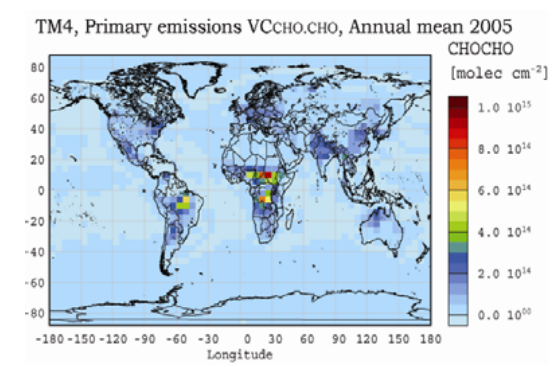

Fig. 2. Global annual mean column distribution of $\mathrm{CHOCHO}$ (in $4^{\circ} \times 6^{\circ}$ grid) for the year 2005 (in molecules $\mathrm{cm}^{-2}$ ):
(a) Simulated by TM4-ECPL taking into account all secondary glyoxal sources (simulation S3).
(b) Simulated by TM4-ECPL taking into account only the CHOCHO source from biogenic VOC oxidation.
(c) Observed by the satellite based sensor SCIAMACHY (reduced spatial resolution)
(d) Simulated by TM4-ECPL to be produced by the anthropogenic VOC oxidation
(e) Simulated by TM4-ECPL to be produced by the biomass burning VOC oxidation
(f) Simulated by TM4-ECPL to result from primary emissions from biomass burning and other combustion sources.

the seasonal variability of the anthropogenic VOC emissions. The calculated hydroxyl radical concentration, the main tropospheric oxidant responsible for $\mathrm{CHOCHO}$ formation, exhibits a strong seasonality, having a summer-to-winter ratio that varies near the surface in the northern troposphere mid-latitudes from about 2 to more than 20, as presented in Fig. 4. The strong seasonality in oxidant levels and biogenic emissions leads to about $25 \%$ higher global production of $\mathrm{CHOCHO}$ during the $\mathrm{NH}$ summer than during the $\mathrm{NH}$ winter (Fig. $3 \mathrm{~g}$ and $\mathrm{h}$ ). In parallel, the losses of $\mathrm{CHOCHO}$ are also about $25 \%$ higher during summer as a result of increased losses of CHOCHO by photodissociation (20\%), by reaction with the $\mathrm{OH}$ radical $(40 \%)$ and by deposition $(25 \%)$. The overall result is an almost $10 \%$ enhancement of the CHOCHO column during NH summer (global burden 0.019 Tg) compared to $\mathrm{NH}$ winter (global burden $0.017 \mathrm{Tg}$ ). The consideration of potential primary sources of CHOCHO (simulation S4) is also introducing significant seasonality since biomass burning emissions maximize during the dry season. The estimated seasonal contribution of this primary source 
(a)

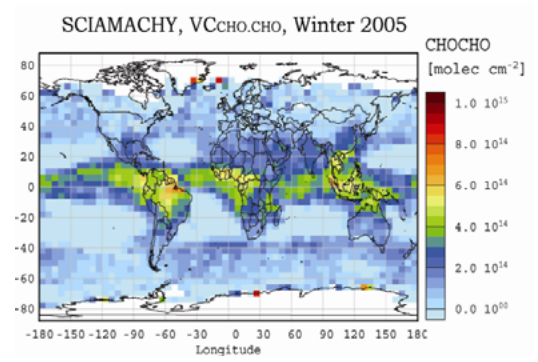

(c)

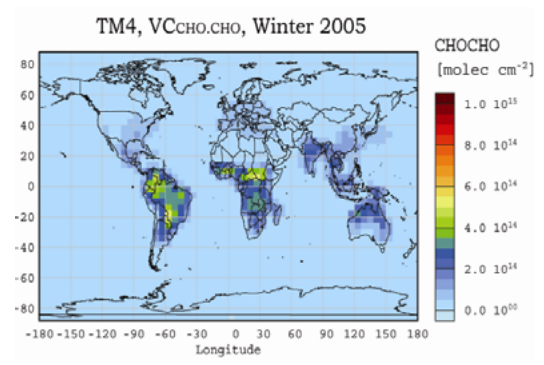

(e)

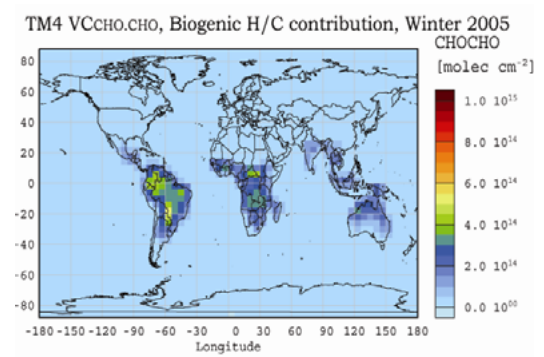

(g)

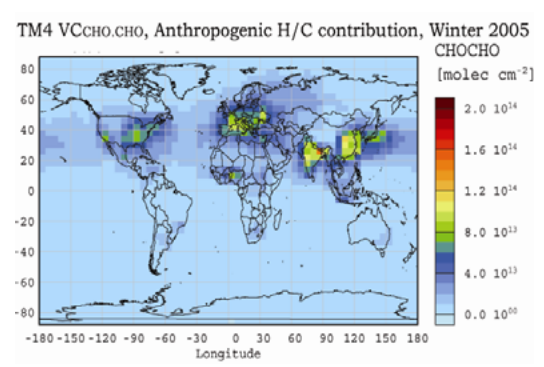

(b)

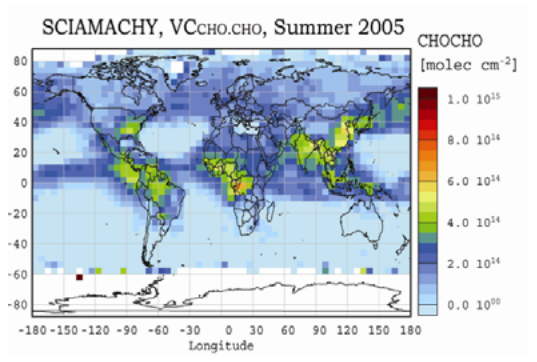

(d)

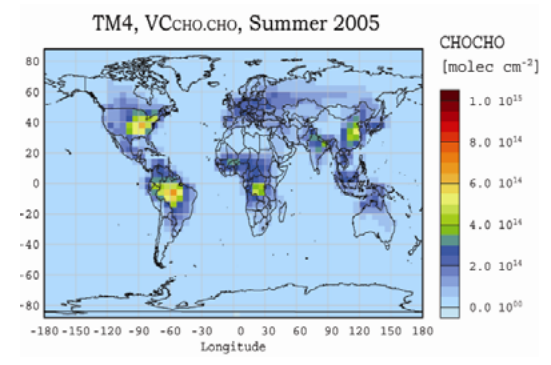

(f)

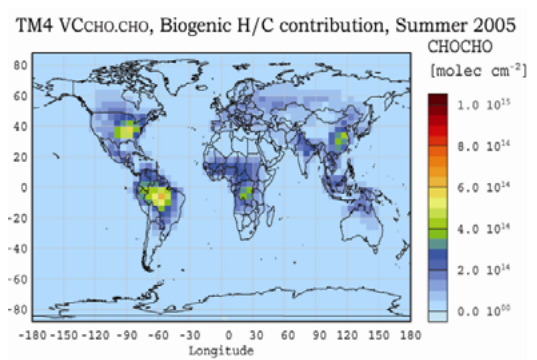

(h)

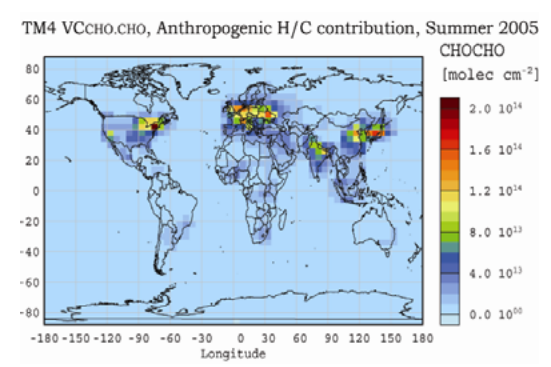

Fig. 3. NH winter (a, c, e, $\mathbf{g}, \mathbf{i}, \mathbf{k})$ and NH summer $(\mathbf{b}, \mathbf{d}, \mathbf{f}, \mathbf{h}, \mathbf{j}, \mathbf{l})$ mean columns of glyoxal as retrieved from SCIAMACHY observations (a, b) and as computed by TM4-ECPL taking into account formation of glyoxal from VOC emitted from (c, d) all sources; (e, f) only biogenic sources; $(g, h)$ only anthropogenic sources and $(i, j)$ only biomass burning, for the year 2005. (k, l) computed CHOCHO columns derived from biomass burning and other combustion primary sources. Columns are given in $10^{15}$ molecules $\mathrm{cm}^{-2}$. Note the different color scale in figures $\mathrm{g}$ to $\mathrm{j}$.

to CHOCHO column is shown in Fig. 3k and 1. Finally, in the present study, a potential aerosol sink of $\mathrm{CHOCHO}$ that could be of relevance for atmospheric conditions is not taken into account, because of our limited current knowledge about this process.

\subsection{Ratios of trace gases columns}

As a result of the strong anthropogenic signal in the $\mathrm{CHO}$ $\mathrm{CHO}$ column, it is expected that synergistic use of $\mathrm{CHOCHO}$ and $\mathrm{HCHO}$ observations from space provides a powerful tool to evaluate the impact of VOC emissions on tropospheric 
(i)

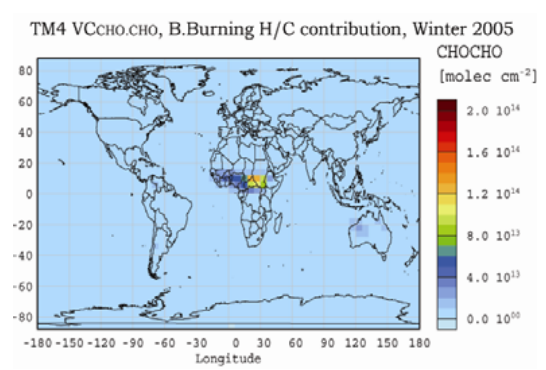

(k)

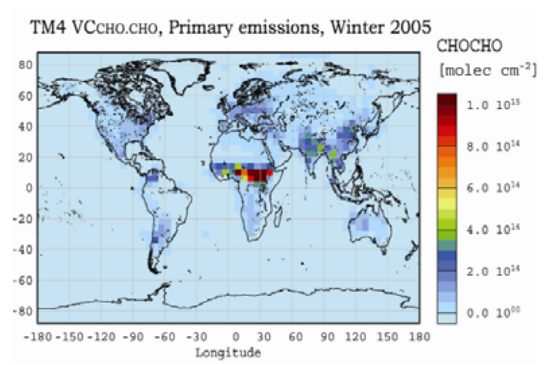

(j)

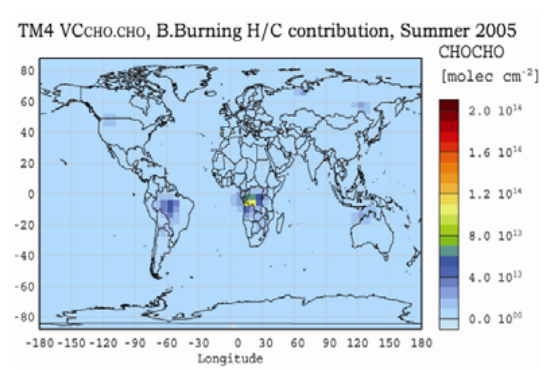

(l)

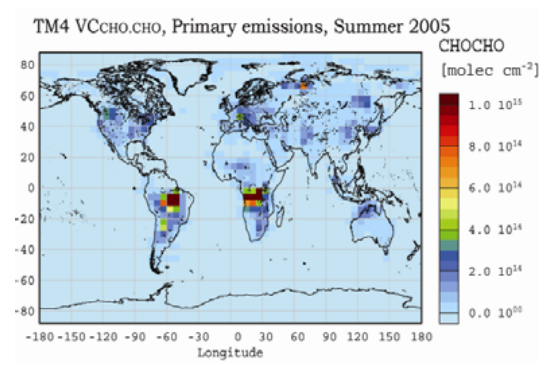

Fig. 3. Continued.

chemistry, as a function of source region and type. This proposition has been investigated by examining the computed ratios of $\mathrm{CHOCHO}$ to $\mathrm{HCHO}$ over the tropics and over the hot-spot areas in the Northern Hemisphere. The satellite observations of $\mathrm{CHOCHO}$ and $\mathrm{HCHO}$ molecules were used to compute the respective ratio above the 30 most populated areas of the world (http://www.infoplease.com/ipa/ A0884418.html). The mean $\mathrm{CHOCHO} / \mathrm{HCHO}$ ratio above these regions is $0.037 \pm 0.014$. This mean ratio is in good agreement with the value of 0.025 observed in Mexico City based on the data provided by Garcia et al. (2006), and taking into account the diurnal profile of these carbonyls to match the satellite overpass time. The same analysis performed above biogenic sources gave an enhanced average value equal to $0.050 \pm 0.025$. This latter number is in good agreement with the range of values $0.04-0.06$ reported by Munger et al. (1995) and Spaulding et al. (2003). These values are contrasted with those computed by the TM4-ECPL model (Fig. 5a): the model calculated ratios, derived from the 10-11 a.m. local time simulations, are in reasonable agreement with the satellite data (not shown) over the selected regions with intense anthropogenic emissions, namely Europe, China, India and the United States. Figure $5 b$ illustrates the same ratio when the anthropogenically produced $\mathrm{CHOCHO}$ is ignored (simulation S2). As expected, the major impact of this photochemical source of $\mathrm{CHOCHO}$ is seen above the Northern Hemisphere urban areas.

The differences in the $\mathrm{CHOCHO}$ to $\mathrm{HCHO}$ ratio between simulations $\mathrm{S} 3$ and $\mathrm{S} 2$ that is attributed to the photochemical source of CHOCHO from human activities is shown in
Fig. $5 \mathrm{c}$ in which the anthropogenically influenced regions are clearly identified.

\subsection{CHOCHO annual global budget}

According to the TM4-ECPL simulations, $\mathrm{CHOCHO}$ global annual chemical production totals $56 \mathrm{Tg} \mathrm{CHOCHO} \mathrm{y}^{-1}$. Approximately $70 \%$ results from the oxidation of biogenics, isoprene and terpenes, among which the predominant portion is formed via formation of glycolaldehyde and hydroxyacetone and subsequent degradation. To a smaller extent CHO$\mathrm{CHO}$ is formed from AVOCs, i.e. $17 \%$ from acetylene, $11 \%$ from aromatics, and 2\% from ethene and propene. According to the TM4-ECPL model simulations, the contribution of anthropogenic VOCs oxidation to the CHOCHO column is limited to $3-20 \%$ over the tropics and maximizes over urban areas and downwind in the Northern Hemisphere, reaching values of $20-70 \%$. However, the $\mathrm{CHOCHO}$ column is relatively low $\left(\sim 2\right.$ to $\sim 410^{14}$ molecules $\left.\mathrm{cm}^{-2}\right)$ in the anthropogenic influenced regions. This is consistent with findings in Mexico City, where aromatics contribute some 70$80 \%$ to the $\mathrm{CHOCHO}$ production rate. A direct comparison of the relative contribution of individual VOC sources and CHOCHO sinks is possible for Mexico City (data from Table 1 of Volkamer et al., 2007) and the Pearl River Delta (Volkamer et al., 2006b), and shows good agreement with the model results of this study. Consideration of primary CHOCHO sources would further increase by about $20 \%$ the anthropogenic and by about $160 \%$ the biomass burning annual CHOCHO sources. TM4-ECPL also evaluates that the glyoxal secondary production from biogenic and biomass 
(a)

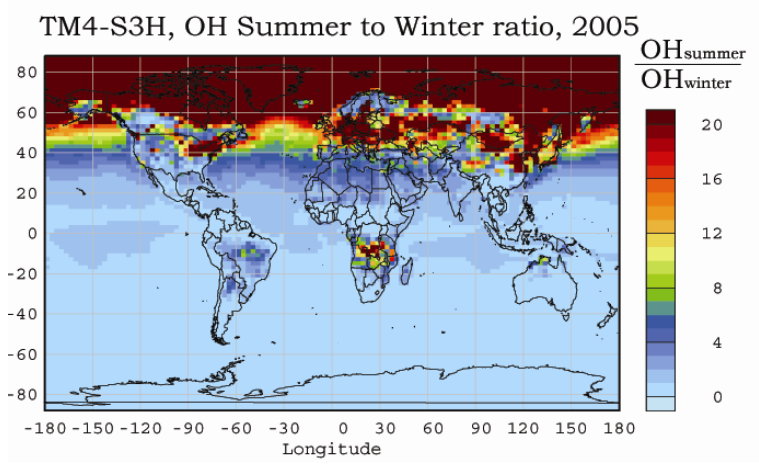

(b)

TM4-S3H, CHO.CHO Summer to Winter ratio, 2005

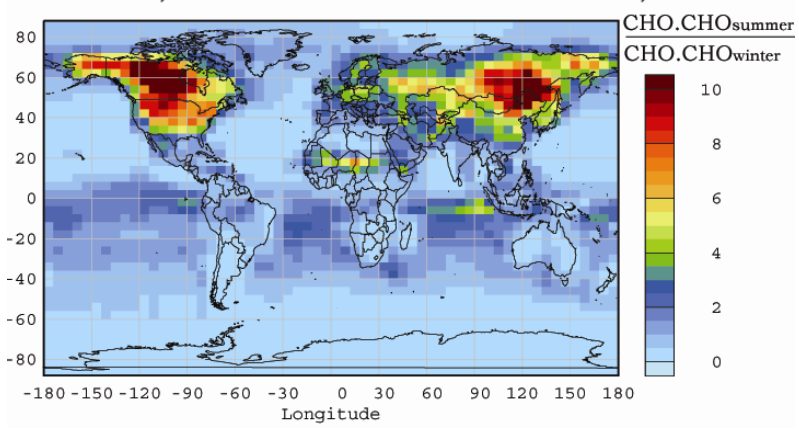

Fig. 4. NH Summer to NH winter ratios of (a) computed OH radical, (b) of computed glyoxal column (simulation S3-H).

burning VOC oxidation has been significantly enhanced (almost doubled) due to the changes in oxidants levels induced from anthropogenic activities.

$\mathrm{CHOCHO}$ is destroyed by photolysis $(63 \%)$, and $\mathrm{OH}$ radical reactions $(23 \%)$, but it is also removed from the atmosphere through wet deposition (8\%) and dry deposition (6\%). As a result, for $\mathrm{CHOCHO}$ the global annual mean burden in the model domain equals $0.02 \mathrm{Tg}$ (equal to the global burden seen by SCIAMACHY over land in the year 2005) and the lifetime is around $3 \mathrm{~h}$.

It is also remarkable that according to our model simulations, on an annual basis about $5 \mathrm{Tg}$ of CHOCHO are removed from the atmosphere via wet deposition. The robustness of this result is investigated by simulation S5 that used a 2 orders of magnitude lower $K_{H}$ for CHOCHO. In that simulation, both the lifetime and the global burden of $\mathrm{CHOCHO}$ increase by about $2 \%$ as a result of a reduction in its wet deposition by about $8 \%$. Note that this loss of CHOCHO in clouds has the potential to form secondary organic aerosol as the result of cloud processing of glyoxal, and has to be considered as an indication of the order of magnitude for glyoxal contribution to SOA formation via this procedure. Recently, Fu et al. (2008) have evaluated this source of SOA from glyoxal at $2.6 \mathrm{Tg} \mathrm{y}^{-1}$. Evidence for glyoxal related SOA forma- (a)

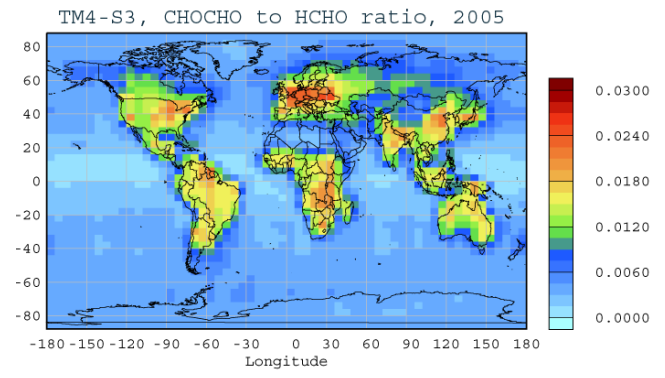

(b)

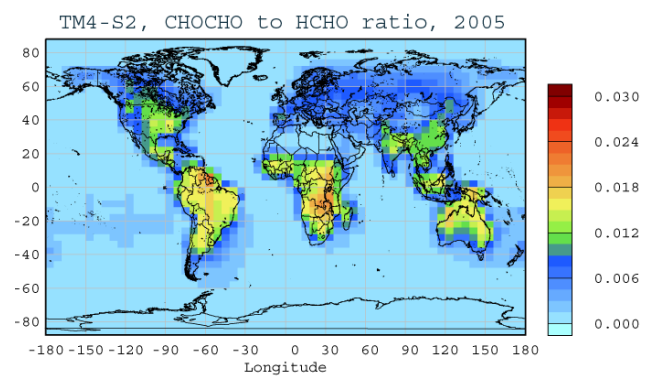

(c)

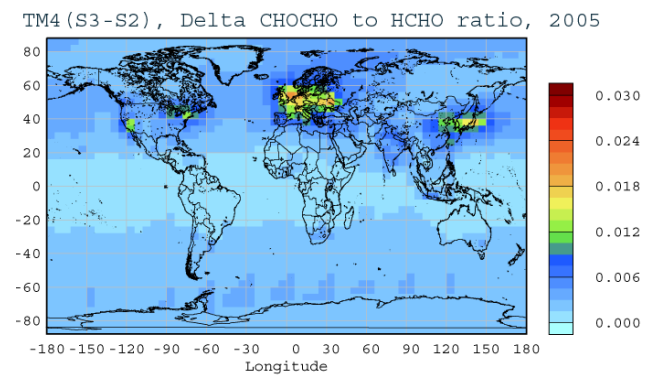

Fig. 5. Annual mean ratios of $\mathrm{CHOCHO}$ to $\mathrm{HCHO}$ as simulated by TM4-ECPL (a): simulation S3 and (b): simulation S2. (c) Difference in this ratio is attributed to the anthropogenic contribution to the CHOCHO column.

tion in the absence of clouds as recently indicated by Volkamer et al. (2007) may however add further SOA. This topic requires further investigation and refinement.

\section{Conclusions}

The global 3-dimensional chemistry/transport model TM4ECPL has been adapted to simulate the temporal and spatial distribution of CHOCHO columns in the global troposphere. This study has focused on the anthropogenic contribution to the CHOCHO column amounts and their seasonality. Aromatics and other hydrocarbons of anthropogenic origin play an important role in determining $\mathrm{CHOCHO}$ column abundances. Wittrock et al. (2006) showed significant amounts of CHOCHO above highly populated regions retrieved from the measurements by the SCIAMACHY sensor aboard ENVISAT. The enhanced CHOCHO columns 
above these regions are confirmed by ground-based satellite validation efforts in Mexico City, and the Pearl River Delta, China (Volkamer et al., 2006b). The global annual chemical production of $\mathrm{CHOCHO}$ has been calculated by the TM4-ECPL model to be $56 \mathrm{Tg}$ CHOCHO $\mathrm{y}^{-1}$. Compounds of anthropogenic origin account for about $30 \%$ of the total chemical production of $\mathrm{CHOCHO}$; acetylene producing about $17 \%$ and aromatic hydrocarbons (toluene, xylene and benzene) about $11 \%$. According to TM4-ECPL model calculations, the contribution of anthropogenic VOC to the CHOCHO column is in the range of $3-20 \%$ over the tropics and maximizes over urban-influenced areas in the Northern Hemisphere where it reaches $70 \%$. Primary emissions of $\mathrm{CHOCHO}$ could increase the anthropogenic contribution to the global annual $\mathrm{CHOCHO}$ source by about $5 \%$. The improvements in the model chemistry of $\mathrm{CHOCHO}$ compared to the earlier study by Wittrock et al. (2006) resulted in better agreement between the model results and the glyoxal observations in the mid latitudes. However, comparison of model results that take into account only the secondary source of $\mathrm{CHOCHO}$ with satellite observations indicates a missing CHOCHO source of about $20 \mathrm{Tg} \mathrm{y}^{-1}$ or an overestimate of its sinks by the model. In particular, the model does not capture the enhancement of CHOCHO columns over the tropical ocean seen by SCIAMACHY. This points to the existence of primary and/or secondary tropical and/or oceanic sources of $\mathrm{CHOCHO}$, currently neglected or underestimated by the model.

Our model simulations evaluate that $5 \mathrm{Tg} \mathrm{CHOCHO} \mathrm{y}^{-1}$ are removed by precipitating clouds. This amount indicates the order of magnitude of a potential $\mathrm{CHOCHO}$ contribution to the SOA formation via multiphase chemistry in clouds. This estimate deserves careful and further refinement. The current limited description of the role of primary production in oceans, the release of particles and organic compounds from oceans, the physics and chemistry of clouds and possibly aerosols introduce significant uncertainties in the modeled $\mathrm{CHOCHO}$ and require further study.

Acknowledgements. This study has been facilitated by the EU Network of Excellence ACCENT. SM. acknowledges support by a PENED 03ED373 grant co-financed by EU-European Social Fund $(75 \%)$ and the Greek Ministry of Development - GSRT (25\%). M. V. acknowledges consecutive supporting fellowships by the A. v. Humbolt Foundation and the EU (Marie Curie - Intra European Fellowships). The research undertaken for this study at the University of Bremen has been supported by the University and State of Bremen. The SCIAMACHY data is a nationally funded contribution to the ESA ENVISAT. We thank K. Feierabend and J. Burkholder for communication of their results prior publication.

Edited by: A. Nenes

\section{References}

Atkinson, R., Baulch, D. L., Cox, R. A., Crowley, J. N., Hampson, R. F., Hynes, R. G., Jenkin, M. E., Rossi, M. J., Troe, J., and IUPAC Subcommittee: Evaluated kinetic and photochemical data for atmospheric chemistry: Volume II - gas phase reactions of organic species, Atmos. Chem. Phys., 6, 3625-4055, 2006, http://www.atmos-chem-phys.net/6/3625/2006/.

Bloss, C., Wagner, V., Jenkin, M. E., Volkamer, R., Bloss, W. J., Lee, J. D., Heard, D. E., Wirtz, K., Martin-Reviejo, M., Rea, G., Wenger, J. C., and Pilling, M. J.: Development of a detailed chemical mechanism (MCMv3.1) for the atmospheric oxidation of aromatic hydrocarbons, Atmos. Chem. Phys., 5, 641664, 2005,

http://www.atmos-chem-phys.net/5/641/2005/.

Bovensmann, H., Burrows, J. P, Buchwitz, M, Frerick, J., Noel, S., Rozanov, V. V. Chance, K. V, and Goede, A. P. H.: SCIAMACHY: Mission objectives and measurement modes, J. Atmos. Sci., 56, 127-150, 1999.

Borrego, C., Gomes, P., Barros, N., and Miranda, A. I.: Importance of handling organic atmospheric pollutants for assessing air quality, J. Chromatography A., 889, 271-279, 2000.

Bracher, A. and Tilzer, M.: Underwater light field and phytoplankton absorbance in different surface water masses of the Atlantic Sector of the Southern Ocean, Pol. Biol., 24, 687-696, 2001.

Burrows, J. P., Hölzle, E., Goede, A. P. H., Visser, H., and Fricke, W.: SCIAMACHY - Scanning Imaging Absorption Spectrometer for Atmospheric Chartography, Acta Astronautica, 35, 5 445451, 1995.

Calvert, J. G., Atkinson, R., Kerr, J. A., Madronich, S., Moortgat, G. K., Wallington, T. J., and Yarwood, G.: The Mechanisms of Atmospheric Oxidation of the Alkenes, Oxford University Press, New York, 2000.

Calvert, J. G., Atkinson, R., Becker, K. H., Kamens, R. M., Seinfeld, J. H., Wallington, T. J., and Yarwood, G.: The Mechanisms of Atmospheric Oxidation of Aromatic Hydrocarbons, Oxford University Press, Oxford, 2002.

Evans, J., Levy, J., Hammitt, J., Santos-Burgoa, C., CastilleJos, M., Caballero-Ramirez, M., Hernandez-Avila, M., RiojasRodriguez, H., Rojas-Bracho, L., Serrano-Trespalacios, P., Spengler, J. D., and Suh, H.: Health benefits of air pollution control, in: Air Quality in the Mexico Megacities: An Integrated Assessment, edited by: Molina, L. T. and Molina, M. J., Kluwer Academic Publishers, 103-136, 2002.

Feierabend, K., Zhu, L., Talukdar, R. K., and Burkholder, J. B.: Rate coefficients for the $\mathrm{OH}+\mathrm{HC}(\mathrm{O}) \mathrm{C}(\mathrm{O}) \mathrm{H}$ (Glyoxal) reaction between 210 and 390 K, J. Phys. Chem. A, 112, 73-82, doi:10.1021/jp0768571, 2008.

Fu, T.-M., Jacob, D. J., Wittrock, F., Burrows, J. P., Vrekoussis, M., and Henze, D.: Global budgets of atmospheric glyoxal and methylglyoxal, and implications for formation of secondary organic aerosols, J. Geophys. Res., 113, D15303, doi:10.1029/2007JD009505, 2008.

Ganzeveld, L. and Lelieveld, J.: Dry deposition parameterization in a chemistry general circulation model and its influence on the distribution of reactive trace gases, J. Geophys. Res., 100, 20 999-21 012, 1995.

García-Alonso, S., Pérez-Pastor, R., and Sevillano-Castaño, M. L.: Determination of glyoxal and methylglyoxal in atmospheric particulate matter by 2,4-dinitrophenylhydrazine derivatisation, 
Toxicological and Environmental Chemistry, 88(3), 445-452, doi:10.1080/02772240600796837, 2006.

Garcia, A. R., Volkamer, R., Molina, L. T., Molina, M. J., Samuelsson, J., Mellqvist, J., Galle, B., Herndon, S., and Kolb, C. E.: Separation of emitted and photochemical formaldehyde in Mexico City using a statistical analysis and a new pair of gas-phase tracers, Atmos. Chem. Phys., 6, 4545-4557, 2006,

http://www.atmos-chem-phys.net/6/4545/2006/.

Gottwald, M., Bovensmann, H., Lichtenberg, G., Noel, S., von Bargen, A., Slijkhuis, S., Piters, A., Hoogeveen, R., von Savigny, C., Buchwitz, M., Kokhanovsky, A., Richter, A., Rozanov, A., Holzer-Popp, T., Bramstedt, K., Lambert, J.-C., Skupin, J., Wittrock, F., Schrijver, H., and Burrows, J. P.: SCIAMACHY, Monitoring the Changing Earth's Atmosphere, Published by DLR, 2006.

Gregg, J. W., Jones, C. G., and Dawson, T. E.: Urbanization, air pollution and tree growth in the vicinity of New York City, Nature, 424, 183-187, 2003.

Granier C., Guenther, A., Lamarque, J.F., Mieville, A., Muller, J. F., Olivier, J., Orlando, J., Peters, J., Petron, G., Tyndall, G., and Wallens, S.: POET, a database of surface emissions of ozone precursors, available on the internet at: http://www.aero.jussieu. fr/project/ACCENT/POET.php, 2005.

Griffin, R. J., Cocker III, D. R., Flagan, R. C., and Seinfeld, J. H.: Organic aerosol formation from oxidation of biogenic hydrocarbons, J. Geophys. Res. 104, 3555-3567, 1999a.

Griffin, R. J., Cocker III, D. R., Seinfeld, J. H. and Dabdub, D.: Estimate of global atmospheric organic aerosol from oxidation of biogenic hydrocarbons, Geophys. Res. Lett. 26, 2721-2724, $1999 b$

Grosjean, E., DeAndrade, J. B., and Grosjean, D.: Carbonyl products of the gas-phase reaction of ozone with simple alkenes, Environ. Sci. Technol., 30, 975-983, 1996a.

Grosjean, E. and Grosjean, D.: The reaction of unsaturated aliphatic oxygenates with ozone, J. Atmos. Chem., 32, 205-232, 1999.

Grosjean, D., Grosjean, E., and Gertler, A. W.: On-Road Emissions of Carbonyls from Light-Duty and Heavy-Duty Vehicles, Environ. Sci. Technol., 35, 45-53, 2001.

Guenther, A., Hewitt, C. N., Erickson, D., Fall, R., Geron, C., Graedel, T., Harley, P., Klinger, L., Lerdau, M., McKay, W. A., Pierce, T., Scholes, B., Steinbrecher, R., Tallamraju, R., Taylor, J., and Zimmerman, P.: A global model of natural volatile organic compound emissions, J. Geophys. Res. 100, 8873-8892, 1995.

Guenther, A., Karl, T., Harley, P., Wiedinmyer, C., Palmer, P. I., and Geron, C.: Estimates of global terrestrial isoprene emissions using MEGAN (Model of Emissions of Gases and Aerosols from Nature), Atmos. Chem. Phys., 6, 3181-3210, 2006, http://www.atmos-chem-phys.net/6/3181/2006/.

Hays, D. M., Geron, D. C., Linna, J. K., Smith, D. M., and Schauer, J. J.: Speciation of Gas- Phase and Fine particle emissions from burning of foliar fuels, Environ. Sci. Technol., 33, 11, 22812295, doi:10.1021/es0111683, 2002.

Heald, C. L., Jacob, D. J., Park, R. J., Russell, L. M., Huebert, B. J., Seinfeld, J. H., Liao, H., and Weber, R. J.: A large organic aerosol source in the free troposphere missing from current models, J. Geophys. Res. 32, L18809, doi:10.1029/2005GL023831, 2005.

Ho, S. S. H. and Yu, J. Z.: Feasibility of collection and analysis of airborne carbonyls by on-sorbent derivatization and thermal desorption, Analytical Chemistry, 74 1232-1240, 2002.

IUPAC Subcommittee on Gas Kinetic Data Evaluation for Atmospheric Chemistry, Summary of Evaluated Kinetic and Photochemical Data for Atmospheric Chemistry, Web Version February, http://www.iupac-kinetic.ch.cam.ac.uk/summary/ IUPACsumm_web_Feb2006.pdf, 2006.

Jeuken, A., Veefkind, J. P., Dentener, F., Metzger, S., and Gonzalez, C. R.: Simulation of the aerosol optical depth over Europe for August 1997 and a comparison with observations, J. Geophys. Res., 106, 28 295-28 311, 2001.

Jang, M. and Kamens, R. M.: Atmospheric secondary aerosol formation by heterogeneous reactions of aldehydes in the presence of a sulfuric acid aerosol catalyst, Environ. Sci. Technol., 35(24), 4758-4766, 2001.

Jing, L. H., Steinberg, S. M., and Johnson, B. J.: Aldehyde and monocyclic aromatic hydrocarbon mixing ratios at an urban site in Las Vegas, Nevada, J. Air Waste Management Association, 51 1359-1366, 2001.

Sander, S.P., Ravishankara, A. R., Golden, D. M., Kolb, C. E, Kurylo, M. J., Molina, M. J., Moortgat, G. K., FinlaysonPitts, B. J., Wine, P. H., Huie, R. E.: Chemical Kinetics and Photochemical Data for Use in Atmospheric Studies Evaluation Number 15, JPL Publication 06-2, available on the web at http://jpldataeval.jpl.nasa.gov/, 2006.

Kanakidou, M. and Crutzen, P. J.: The photochemical source of carbon monoxide: Importance, Uncertainties and feedbacks, Chemosphere: Global Change Science, 1, 91-109, 1999.

Kanakidou, M., Seinfeld, J. H., Pandis, S. N., Barnes, I., Dentener, F. J., Facchini, M. C., van Dingenen, R., Ervens, B., Nenes, A., Nielsen, C. J., Swietlicki, E., Putaud, J. P., Balkanski, Y., Fuzzi, S., Horth, J., Moortgat, G. K., Winterhalter, R., Myhre, C. E. L., Tsigaridis, K., Vignati, E., Stephanou, E. G., and Wilson, J.: Organic aerosols and global climate modeling: a review, Atmos. Chem. Phys., 5, 1053-1123, 2005,

http://www.atmos-chem-phys.net/5/1053/2005/.

Kawamura, K., Kasukabe, H., and Barrie, L. A.: Source and reaction pathways of dicarboxylic acids, ketoacids and dicarbonyls in arctic aerosols: One year of observations, Atmos. Environ., 30, 1709-1722, 1996.

Kawamura, K., Steinberg S., and Kaplan I. R.: Homologous series of C-1-C-10 monocarboxylic acids and C-1-C-6 carbonyls in Los Angeles air and motor vehicle exhausts, Atmos. Environ., 34, 4175-4191, 2000.

Kean, A. J., Grosjean, E., Grosjean, D., and Harley, R. A.: OnRoad Measurement of Carbonyls in California Light-Duty Vehicle Emissions, Environ. Sci. Technol., 35, 4198-4204, 2001.

Kroll, J. H., Ng, N. L., Murphy, S. M., Varutbangkul, V., Flagan, R. C., and Seinfeld, J. H.: Chamber studies of secondary organic aerosol growth by reactive uptake of simple carbonyl compounds, J. Geophys. Res., 110, D23207, doi:10.1029/2005JD006004, 2005.

Landgraf, J. and Crutzen, P. J.: An efficient method for online calculation of photolysis and heating rates, J. Atmos. Sci., 55, 863878, 1998.

Lelieveld, J., Peters, W., Dentener, F. J., and Krol, M. C.: Stability of tropospheric hydroxyl chemistry, J. Geophys. Res., 107, 4715, doi:10.1029/2002JD002272, 2002.

Lee, Y. N., Zhou, X. L., and Hallock, K.: Atmospheric carbonyl 
compounds at a rural southeastern United States site, J. Geophys. Res. - Atmos., 100, 25 933-25 944, 1995.

Liggio, J. and McLaren, R.: An optimized method for the determination of volatile and semi-volatile aldehydes and ketones in ambient particulate matter, International Journal of Environmental Analytical Chemistry, 83, 819-835, 2003.

Liggio, J., Li, S. M., and McLaren, R.: Heterogeneous reactions of glyoxal on particulate matter identification of acetals and sulfate esters. Environ. Sci. Technol., 39, 1532-1541, 2005a.

Liggio, J., Li, S. M., and McLaren, R.: Reactive uptake of glyoxal by particulate matter. J. Geophys. Res., 110, D10304, doi:10310.11029/2004JD005113, 2005b.

Lim, H. J., Carlton A. G., and Turpin, B. J.: Isoprene forms secondary organic aerosol through cloud processing: Model simulations, Environ. Sci. Technol., 39, 4441-4446, 2005.

Loeffler, K. W., Koehler, C. A., Paul, N. M., and de Haan, D. O.: Oligomer Formation in Evaporating Aqueous Glyoxal and Methyl Glyoxal Solutions, Environ. Sci. Technol., 40, 63186323, 2006

Matsunaga, S., Mochida, M., and Kawamura, K.: Growth of organic aerosols by biogenic semi-volatile carbonyls in the forestal atmosphere, Atmos. Environ., 37, 2045-2050, 2003.

Moortgat, G. K., Grossmann, D., Boddenberg, A., Dallmann, G., Ligon, A. P., Turner, W. V., Gab, S., Slemr, F., Wieprecht, W., Acher, K., Kilber, M., Schlomski, S., and Bachmann, K.: Hydrogen Peroxide, Organic Peroxides and Higher Carbonyl Compounds Determined during the BERLIOZ Campaign, J. Atmos. Chem. 42, 443-463, 2002.

Munger, J. W., Jacob, D. J., Daube, B. C., Horowitz, L. W., Keene, W. C. and Heikes B. G.: Formaldehyde, glyoxal, and methylglyoxal in air and cloudwater at a rural mountain site in central Virginia, J. Geophys. Res., 100, 9325-9334, 1995.

Olivier, J., Peters, J., Granier, C., Petron, G., Muller, J. F., and Wallens, S.: Present and Future surface emissions of anthropogenic compounds, POET report \#2, EU project EVK2-1999-00011, 2003.

Palmer, P. I., Jacob, D. J., Fiore, A. M., Martin, R. V., Chance, K., and Kurosu, T. P.: Mapping isoprene emissions over North America using formaldehyde column observations from space, J. Geophys. Res., 108(D6), 4180, doi:10.1029/2002JD002153, 2003.

Poisson, N., Kanakidou, M., and Crutzen, P. J.: Impact of Non Methane Hydrocarbons on tropospheric chemistry and particular the oxidizing power of the global troposphere: 3-Dimensional Modelling results, J. Atmos. Chem., 36, 157-230, 2000.

Poisson, N., Kanakidou, M., Bonsang, B., Behmann, T., Burrows, J., Gölz, C., Harder, H., Lewis, A., Moortgat, G. K., Nunes, T., Pio, C., Platt, U., Sauer, F., Schuster, G., Seakins, P., Senzig, J., Seuwen, R., Trapp, D., Voltz-Thomas, A., Zenker, T., and Zitzelberger, R.: The Impact of Natural NonMethane Hydrocarbon Oxidation on the Free Radical and Ozone budgets above a Eucalyptus forest, Chemosphere, Global Change Science, 3, 353-366, 2001.

Pope, C. A. and Dockery, D.W.: Health effects of fine particulate air pollution: Lines that connect. J Air and Waste Management Association. 54, 709-742, 2006.

Ramanathan, V. and Crutzen, P. J.: New directions: Atmospheric brown "Clouds", Atmos. Environ., 37, 4033-4035, 2003.

Saxena, P. and Hildemann, L. M.: Water-Soluble Organics in At- mospheric Particles: A Critical Review of the Literature and Application of Thermodynamics to Identify Candidate Compounds, J. Atmos. Chem., 24, 57-109, 1996.

Saunders, S. M., Jenkin, M. E., Derwent, R. G., and Pilling, M. J.: Protocol for the development of the Master Chemical Mechanism, MCM v3 (Part A): tropospheric degradation of nonaromatic volatile organic compounds, Atmos. Chem. Phys., 3, 161-180, 2003

Singh, H. B., Salas, L. J., Chatfield, R. B., Czech, E., Fried, A., Walega, J., Evans, M. J., Field, B. D., Jacob, D. J., Blake, D., Heikes, B., Talbot, R., Sachse, G., Crawford, J. H., Avery, M. A., Sandholm, S., and Fuelberg, H.: Analysis of the atmospheric distribution, sources, and sinks of oxygenated volatile organic chemicals based on measurements over the Pacific during TRACE-P, J. Geophys. Res., 109, D15S07, doi:10.1029/2003JD003883, 2004.

Sinreich, R., Volkamer, R., Filsinger, F., Frieß, U., Kern, C., Platt, U., Sebastián, O., and Wagner, T.: MAX-DOAS detection of glyoxal during ICARTT 2004, Atmos. Chem. Phys., 7, 1293-1303, 2007 , http://www.atmos-chem-phys.net/7/1293/2007/.

Shindell, D. T., Faluvegi, G., Stevenson, D. S., Emmons, L. K., Lamarque, J. F., Petron G., Dentener, F. J., Ellingsen K., Eskes, H., and van Noije, T. P. C.: Multi-model simulations of carbon monoxide: Comparison with observations and projected near-future changes, J. Geophys. Res., 111, D19306, doi:10.1029/2006JD007100, 2006.

Sorooshian, A., Lu, M. L., Brechtel, F. J., Jonsson, H., Feingold, G., Flagan, R. C., and Seinfeld, J. H.: On the source of organic acid aerosol layers above clouds, Environ. Sci. Technol., 41, 46474654, 2007.

Spaulding, R. S., Schade, G. W., Goldstein, A. H., and Charles, M. J.: Characterization of secondary atmospheric photoxidation products: Evidents for biogenic and anthropogenic sources, J. Geophys. Res., 108 D(8), 4247 doi:10.1029/2002JD002478, 2003.

Stevenson, D. S., Dentener, F. J., Schultz, M. G., Ellingsen, K., and van Noije., T. P. C.: Multimodel ensemble simulations of present-day and near-future tropospheric ozone. J. Geophys. Res., 111, D08301, doi:10.1029/2005JD006338, 2006.

Tadic, J., Moortgat, G. K., and Wirtz, K.: Photolysis of glyoxal in air, Journal of Photochemistry and Photobiology A: Chemistry, 177, 116-124, 2006.

Tsigaridis, K. and Kanakidou, M.: Global modeling of secondary organic aerosol in the troposphere: a sensitivity analysis, Atmos. Chem. Phys. 3, 1849-1869, 2003.

Tsigaridis, K., Krol, M., Dentener, F. J., Balkanski Y., Lathiere J., Metzger S., Hauglustaine, D. A., and Kanakidou, M.: Change in global aerosol composition since preindustrial times, Atmos. Chem. Phys., 6, 5143-5162, 2006, http://www.atmos-chem-phys.net/6/5143/2006/.

Tsigaridis, K. and Kanakidou, M.: Secondary organic aerosol importance in the future atmosphere, Atmos. Environ., 41, 46824692, doi:10.1016/j.atmosenv.2007.03.045, 2007.

Van Noije, T. P. C., van Eskes, H. J., van Weele, M., and van Velthoven, P. F. J.: Implications of the enhanced Brewer-Dobson circulation in European Centre for Medium-Range Weather Forecasts reanalysis ERA-40 for the stratosphere-troposphere exchange of ozone in global chemistry transport models, J. Geo- 
phys. Res. 109, D19308, doi:10.1029/2004JD004586, 2004.

Van Noije, T. P. C. van Eskes H. J., Dentener, F. J., Stevenson, D. S., Ellingsen, K., Schultz, M. G., and Wild, O.: Multi-model ensemble simulations of tropospheric $\mathrm{NO}_{2}$ compared with GOME retrievals for the year 2000, Atm. Chem. Phys., 6, 2943-2979, 2006.

Velasco, E., Lamb, B., Westberg, H., Allwine, E., Sosa, G., ArriagaColina, J. L., Jobson, B. T., Alexander, M. L., Prazeller, P., Knighton, W. B., Rogers, T. M, Grutter, M. Herndon, S. C., Kolb, C. E., Zavala, M., de Foy, B., Volkamer, R., Molina, L. T., and Molina, M. J.: Distribution, magnitudes, reactivities, ratios and diurnal patterns of volatile organic compounds in the Valley of Mexico during the MCMA 2002 \& 2003 field campaigns, Atmos. Chem. Phys., 7, 329-353, 2007,

http://www.atmos-chem-phys.net/7/329/2007/.

Volkamer, R., Platt, U., and Wirtz, K.: Primary and secondary glyoxal formation from aromatics: experimental evidence for the bicycloalkyl-radical pathway from benzene, toluene, and pxylene, J. Phys. Chem. A, 105, 7865-7874, 2001.

Volkamer, R., Barnes, I., Platt, U., Molina, L. T., and Molina, M. J.: Remote Sensing of Glyoxal by Differential Optical Absorption Spectroscopy (DOAS): Advancements in simulations champers and field experiments, paper presented at Advanced Research Workshop on Environmental Simulation Chambers: Application to Atmospheric Chemical Processes, NATO, Zakopane, Poland, 1-4 October, 2005a.

Volkamer, R., Molina, L. T., Molina, M. J., Shirley, T., and Brune, W. H.: DOAS measurement of glyoxal as an indicator for fast VOC chemistry in urban air, Geophys. Res. Lett., 32, L08806, doi:10.1029/2005GL022616, 2005b.

Volkamer, R., Spietz, P., Burrows, J., and Platt U.: High-resolution absorption cross-section of glyoxal in the UV-vis and IR spectral ranges, J. Photochemistry and Photobiology A: Chemistry 172, 35-46, $2005 \mathrm{c}$.

Volkamer, R., Jimenez, J. L, Martini, F. S., Dzepina, K., Zhang, Q., Salcedo, D., Molina, L. T., Worsnop, D. R., and Molina, M. J.: Secondary organic aerosol formation from anthropogenic air pollution: Rapid and higher than expected, Geophys. Res. Lett., 33, L17811, doi:10.1029/2006GL026899, 2006a.
Volkamer, R., Kurosu, T. P., Chance, K., Li, Z., Zhang, Y., Brauers, T., and Wahner, A.: Spatial Variability of Glyoxal, HCHO and NO2 during PRD-2006: Comparison of mobile Mini-MAXDOAS and OMI satellite data in the Pearl River Delta, China. Eos Trans. AGU, 87(52), Fall Meet. Suppl., Abstract A31B-0897, $2006 b$.

Volkamer, R., San Martini, F., Salcedo, D., Molina, L. T., Jimenez, J. L., and Molina, M. J.: A Missing Sink for Gas-Phase Glyoxal in Mexico City: Formation of Secondary Organic Aerosol, Geophys. Res. Lett., 34, L19807, doi:10.1029/2007GL030752,2007.

Vountas, M., Dinter, T., Bracher, A., Burrows, J. P., and Sierk, B.: Spectral studies of ocean water with space-borne sensor SCIAMACHY using Differential Optical Absorption Spectroscopy (DOAS), Ocean Sci., 3, 429-440, 2007, http://www.ocean-sci.net/3/429/2007/.

Vrekoussis, M., Kanakidou, M., Mihalopoulos, M., Crutzen, P. J., Lelieveld, J., Perner, D., Berresheim, H., and Baboukas, E.: Role of the $\mathrm{NO}_{3}$ radicals in oxidation processes in the eastern Mediterranean troposphere during the MINOS campaign, Atmos. Chem. Phys., 4, 169-182, 2004, http://www.atmos-chem-phys.net/4/169/2004/.

Wittrock, F., Oetjen, H., Richter, A., Fietkau, S., Medeke, T., Rozanov, A., and Burrows, J. P.: MAX-DOAS measurements of atmospheric trace gases in Ny-Alesund-Radiative transfer studies and their application, Atmos. Chem. Phys., 4, 955-966, 2004, http://www.atmos-chem-phys.net/4/955/2004/.

Wittrock, F., Richter, A., Oetjen, H., Burrows, J.P., Kanakidou, M., Myriokefalitakis, S., Volkamer, R., Beirle, S., Platt, U., and Wagner, T.: Simultaneous Global Observations of Glyoxal and Formaldehyde from Space, Geophys. Res. Lett., 33, L16804, doi:10.1029/2006GL026310, 2006.

Wesely, M. L.: Parameterization of surface resistances to gaseous dry deposition in regional scale numerical models, Atmos. Environ., 23, 1293-1304, 1989. 